\title{
Sphingolipid Metabolism: New Insight into Ceramide-Induced Lipotoxicity in Muscle Cells
}

\author{
Cécile L. Bandet ${ }^{1,2}$, Sophie Tan-Chen ${ }^{1,2}$, Olivier Bourron ${ }^{1,2,3}$, Hervé Le Stunff ${ }^{4}$ \\ and Eric Hajduch 1,2,* \\ 1 INSERM UMRS 1138, Sorbonne Université; Sorbonne Paris Cité, Université Paris Descartes, \\ Université Paris Diderot; Centre de Recherche des Cordeliers, 75006 Paris, France; \\ cecile.bandet@gmail.com (C.L.B.); sophie.tan@crc.jussieu.fr (S.T.-C.); olivier.bourron@aphp.fr (O.B.) \\ 2 Institut Hospitalo-Universitaire ICAN, 75013 Paris, France \\ 3 Sorbonne Université, Assistance Publique-Hôpitaux de Paris, Service de Diabétologie et Maladies \\ Métaboliques, Hôpital Pitié-Salpêtrière, 75013 Paris, France \\ 4 CNRS UMR 9198 Institut des Neurosciences Paris Saclay (Neuro-PSI), Université Paris-Saclay, \\ 91400 Orsay, France; herve.le-stunff@paris7.jussieu.fr \\ * Correspondence: eric.hajduch@crc.jussieu.fr; Tel.: +33-144-272-467
}

Received: 12 December 2018; Accepted: 18 January 2019; Published: 24 January 2019

\begin{abstract}
Insulin-resistance is a characteristic feature of type 2 diabetes (T2D) and plays a major role in the pathogenesis of this disease. Skeletal muscles are quantitatively the biggest glucose users in response to insulin and are considered as main targets in development of insulin-resistance. It is now clear that circulating fatty acids (FA), which are highly increased in T2D, play a major role in the development of muscle insulin-resistance. In healthy individuals, excess FA are stored as lipid droplets in adipocytes. In situations like obesity and T2D, FA from lipolysis and food are in excess and eventually accumulate in peripheral tissues. High plasma concentrations of FA are generally associated with increased risk of developing diabetes. Indeed, ectopic fat accumulation is associated with insulin-resistance; this is called lipotoxicity. However, FA themselves are not involved in insulin-resistance, but rather some of their metabolic derivatives, such as ceramides. Ceramides, which are synthetized de novo from saturated FA like palmitate, have been demonstrated to play a critical role in the deterioration of insulin sensitivity in muscle cells. This review describes the latest progress involving ceramides as major players in the development of muscle insulin-resistance through the targeting of selective actors of the insulin signaling pathway.
\end{abstract}

Keywords: sphingolipids; ceramide; insulin; diabetes; DAG

\section{Introduction}

A worldwide obesity and diabetes epidemic has been spreading in humans all over the world in the last four decades. According to the World Health Organization, in 2014, 422 million people had diabetes compared to 108 million in 1980. Estimates report that in 2045, the number of diabetics will reach at least 629 million [1]. Diabetes is a condition that is characterized by a chronic hyperglycemia. After several years of unbalanced diabetes, complications altering the quality of life of patients appear and can lead to premature death. These complications are classified into two groups: microvascular complications, such as retinopathy, neuropathy, and nephropathy; and macrovascular complications, such as stroke and myocardial infarction [2]. There are two main types of diabetes: (i) type 1 diabetes (T1D), resulting from a total insulin deficiency (insulinopenia) subsequent of destruction of insulin-producing cells, which accounts for $10 \%$ of diabetes cases; and (ii) type 2 diabetes (T2D), the most common diabetes ( $90 \%$ of diabetes cases), characterized by two major cell 
dysfunctions: insulin resistance of peripheral organs such as liver, adipose tissue, and skeletal muscles, and partial insulinopenia from the $\beta$-cells. Insulin resistance results in a failure of insulin-sensitive tissues to respond to the insulin signal. T2D is associated with many susceptibility genes whose expression depends on environmental factors, such as the level of physical activity, and both hyper-carbohydrate and high fat diets [3]. As soon as insulin resistance appears, the pancreas produces more insulin to maintain normoglycemia. However, when the insulin secretory function is insufficient to counterbalance increasing insulin resistance, hyperglycemia appears. This insulin secretion dysfunction is linked to genetic/epigenetic and environmental factors [4].

T2D is concomitant with alterations of carbohydrate/lipid metabolism, and particularly of dyslipidemia, which have major consequences for cardiovascular diseases and insulin resistance, a key actor of T2D. During obesity, ectopic fatty acids (FA) accumulated into non-adipose tissues are metabolized as sphingolipid derivatives, such as ceramides. Interestingly, ceramides are among the most active lipid second messengers to inhibit key proteins of the insulin signaling pathway and to induce $\beta$-cell apoptosis. Defining new therapeutic targets to treat these metabolic disorders and their subsequent complications is one of the major challenges for clinical research in the future.

Although ceramide excess can affect all insulin-sensitive tissues, we will focus this review on the impact of these lipids on skeletal muscle, tissue that is responsible for 30\% of basal glucose utilization, and from 70 to $90 \%$ in response to insulin in healthy individuals [5-8]. Indeed, skeletal muscles are major tissues for the maintenance of normoglycemia and are therefore a primary target for insulin resistance [9]. We will provide an overview of our present understanding of known machineries and mechanisms by which ceramides affect negatively glucose homeostasis in skeletal muscles.

\section{Type 2 Diabetes Pathophysiology: From Physiological Insulin Signaling to Energy Homeostasis Disruption}

Insulin is an anabolic hormone which induces many metabolic pathways in its different target tissues, resulting in a hypoglycemic effect. These cellular responses are the result of the activation of a very specific cascade signaling pathway whose mechanisms are now well characterized.

Initially, insulin binds its receptor, which is localized in the plasma membrane (PM) of most cells, but much more so in "insulin-sensitive" cells (liver, adipose tissue, skeletal muscles, and heart) [10]. The insulin receptor (IR) consists of four subunits organized into a heterodimer: two extracellular $\alpha$ subunits that bind to insulin, and two transmembrane $\beta$ subunits that possess tyrosine kinase activity [10]. When bound to its receptor, insulin induces its transphosphorylation on tyrosine residues, allowing its activation [11]. Activated receptors then phosphorylate several intracellular substrates, such as Src homology collagen (Shc) protein, APS (adaptor protein with PH domain and a Src homology 2 (SH2) domain) proteins, and insulin receptor substrates (IRS) [11].

There are six different isoforms of IRS, but only the first two are involved in insulin signal transduction. IRS1 is the isoform predominantly expressed in adipose tissue and skeletal muscle. It plays a crucial role in the propagation of the insulin signal in these tissues $[12,13]$. In the liver, IRS2 is expressed [12]. IRS3 exists in rodents but not in humans [14]. The IRS4 isoform is not involved in insulin signaling since its invalidation does not affect carbohydrate homeostasis in a murine model [15]. Both IRS5 and IRS6 isoforms do not transmit insulin signals [14]. Insulin-activated IR phosphorylates IRS on various specific tyrosine residues (tyrosine 612 in the case of IRS1), allowing their recognition by proteins with SH2 domains, such as Class IA phosphoinositide-3-kinase (PI3K). Activated PI3K phosphorylates phosphatidylinositol diphosphate (PIP2) to give phosphatidylinositol triphosphate (PIP3) [16], and synthesized PIP3 recruits to the PM a kinase playing a pivotal role in the transmission of the insulin signal, Akt (or protein kinase B, PKB) [17-19].

There are three different isoforms of Akt. Akt1 is expressed ubiquitously in cells, Akt2 is expressed predominantly in insulin-sensitive tissues, and Akt3 is mainly found in the brain [20]. Akt recruitment to the PM induces its conformational change and releases two amino acids whose phosphorylation is essential for the complete activation of the kinase. The mTORC2 (mammalian 
target of rapamycin (mTOR) complex 2) complex phosphorylates Akt on its serine 473, whereas phosphoinositide-dependent kinase 1 (PDK1) phosphorylates Akt on its threonine 308 site [18].

Akt relays the effects of insulin action in its different target tissues. In skeletal muscle and adipocytes, insulin-activated Akt induces glucose uptake via the recruitment of a specific glucose transporter, GLUT4 at the PM [21]. GLUT4 is highly expressed in skeletal muscle and adipose tissue. In the absence of insulin, GLUT4-containing vesicles are located inside the cells and less than $5 \%$ of total GLUT4 is found at the PM [22]. Upon insulin action, GLUT4-containing vesicles are recruited to the PM (30 to 50\% of GLUT4 is recruited at the PM), thus allowing glucose to enter the cells [23]. In the liver and skeletal muscle, Akt phosphorylates and inhibits glycogen synthase kinase 3 (GSK3), thus allowing glycogen synthase to induce both glycogen synthesis and storage in hepatocytes and muscle cells [24]. In $\beta$-cells and the liver, the expressed glucose transporter is GLUT2, which transports glucose, fructose, and galactose, independently from insulin [25].

In healthy people, the balance between glucose production and its utilization is finely tuned. When blood glucose reaches a critical threshold level, pancreatic $\beta$-cells secrete insulin. Insulin has two major actions: to lower circulating glucose levels by facilitating its uptake, mainly into skeletal muscle, while inhibiting its production by the liver; and to promote the storage of available nutrients. Normally, the unconsumed fraction of fatty acids is stored in lipid droplets that are localized in adipocytes to provide energy during fasting periods. However, in the case of obesity, when the buffering action of adipose tissues to store fatty acids is impaired, non-adipose tissues (e.g., muscle, liver, and pancreatic $\beta$-cells) accumulate fatty acids, leading to a phenomenon called lipotoxicity. Accumulation of lipids and of their sphingolipid derivatives, such as ceramides, induces cellular toxicity and insulin signaling defects, leading to insulin resistance. Insulin resistance results in a failure of insulin-sensitive tissues to respond to the insulin signal. As soon as insulin resistance appears, the pancreas produces more insulin to maintain normoglycemia. However, when insulin secretory function is insufficient to counterbalance increasing insulin resistance, which correspond to the $\beta$-cell failure, hyperglycemia and T2D appears. This insulin secretion dysfunction is linked to genetic/epigenetic predisposition, and cellular lipotoxicity could also precipitate the relative insulin secretion deficiency.

\section{Lipotoxicity and Muscle Insulin Resistance}

During T2D, peripheral tissues lose their ability to respond to insulin. Tissue insulin resistance is multifactorial, and its starting point is still very much debated. Considering the contribution of muscle in glucose uptake in response to insulin [9], muscles play a major role in the establishment of peripheral insulin resistance. In addition, several studies have shown that muscle insulin resistance contributes significantly to the systemic alteration of glucose metabolism [26-29].

In case of a large FA supply, FA are esterified into triglycerides (TG) and stored in the adipose tissue to avoid their accumulation in the circulation. Adipose tissue can provide this buffer function with its expansion capabilities. However, when adipose tissue reaches its maximum expansion capacity and can no longer perform its storage function, circulating free FA concentrations are at least doubled in obese and T2D individuals compared with lean and healthy subjects [30], and excess lipids accumulate in other peripheral tissues, such as muscles, liver, and pancreas. In addition, low-grade inflammation is observed in adipose tissue of obese individuals [31], leading to an increase in adipocyte lipolysis, which thus contributes to an increase in plasma FA concentrations [32]. Maintenance of adipose tissue expansion is therefore very important to avoid lipid ectopic accumulation. Indeed, absence of white adipose tissue in mice induces rapid ectopic accumulation of lipids in peripheral tissues such as liver and skeletal muscle $[33,34]$. Interestingly, muscle fiber lipid content is twice as abundant in obese T2D patients compared to lean individuals $[35,36]$. In this situation, an adaptation of TG metabolism occurs. Expressions of FA transporters (fatty acid binding protein, FABP, and FA translocase, FAT/CD36) in myocyte PMs are augmented when the FA concentrations are increased in non-obese individuals on a high-fat diet for four weeks [37]. It has also been observed in obese or T2D individuals that long chain 
FA transport into giant sarcolemmal vesicles was four times greater than what was observed in muscle cells of healthy individuals [38].

Despite the increase in FA transport, oxidative capacities of muscle cells are non-adequate for the amounts of FA arriving in these cells. Activities of CPT1 (carnitine palmitoyltransferase 1), citrate synthase (the first enzyme in the Krebs cycle), and cytochrome c oxidase (or complex IV of the mitochondrial respiratory chain catalyzing the transfer of electrons to a molecule of $\mathrm{O}_{2}$, while contributing to the $\mathrm{H}^{+}$proton gradient), are decreased in muscles of obese patients compared to the muscles of lean individuals [6]. In addition, muscles of obese or T2D individuals contain fewer mitochondria and are reduced in size [39-41], leading to a decrease in the oxidative capacities of muscle cells [42]. It has also been shown in extremely obese female individuals (with a body mass index over $53 \mathrm{~kg} / \mathrm{m}^{2}$ ) that $\beta$-oxidation was $58 \%$ and $83 \%$ lower than muscle strips from lean and moderately obese subjects, respectively [43].

In addition to oxidation defects, the saturation state of FA greatly influences their fate. In fact, saturated FA are much less oxidized than unsaturated FA [44], and they accumulate much more in tissues in lipid excess conditions. Increased entry of FA is thus accompanied by a decrease of the oxidative capacities of the muscle cells, leading to lipid accumulation and the onset of insulin resistance.

\subsection{Relationship Between FA and Insulin Resistance: Randle Cycle Hypothesis}

Until 15-20 years ago, the classic "Randle cycle" hypothesis was the best explanation for understanding the reciprocal relationship between carbohydrate metabolism and lipid metabolism, and particularly the deleterious role of fatty acids on glucose metabolism in insulin-sensitive tissues.

In 1963, Randle proposed the existence of a "glucose-fatty acid" cycle that would play a crucial role in the development of cellular insulin resistance [45]. He showed that the substantial increase in intracellular free FA concentrations would result in an increase in circulating glucose and a decrease in its uptake by the cells. Randle and his team showed that the high amount of FA available in cells led to an increase in $\beta$-oxidation, inducing a massive increase in citrate content. This citrate would then inhibit phospho-fructo kinase (PFK), thereby inducing an increase in intracellular glucose-6-phosphate (G6P) and an inhibition of hexokinase, protein responsible for glucose phosphorylation into G6P. Glucose levels would therefore increase in cells, preventing more circulating glucose to be transported into cells [45].

It was not until the early 1990s that new studies put this cycle back into question. Some predictions of the Randle cycle have been jeopardized by the use of new techniques, such as nuclear magnetic resonance, which allowed measurement of metabolite concentrations in tissues in vivo. Furthermore, contrary to what Randle predicted, this technique showed that free FA accumulation induced a decrease in intracellular G6P levels [46], despite the decrease in glucose transport into cells [46]. Thus, Randle's glucose-fatty acid cycle did not explain how FA modulate insulin action and glucose metabolism in insulin sensitive tissues.

\subsection{Lack of Direct Link between FA and Insulin Resistance}

Skeletal muscle is an important site for the clearance of lipoproteins containing TG-derived FA [39]. Most of these FA are sent to esterification in TG. Indeed, $60 \%$ of circulating FA contribute to intracellular TG [39]. Intramyocyte TG concentrations are significantly increased in obese and diabetic subjects compared with intramyocyte TG concentrations from healthy subjects [47]. However, the involvement of TG as primary initiators of the onset of insulin resistance in muscle cells is far from clear. Overexpression of the FAT/CD36 FA transporter in skeletal muscle has been shown to counteract insulin resistance induced by a fatty diet via increased myotube oxidative capacities, despite increased TG concentrations in cells [32].

Interestingly, there is a situation of muscle lipid accumulation that is associated with a very good insulin sensitivity. This is the "athlete paradox". Athletes' muscles accumulate as much intramyocyte lipids as insulin-resistant obese muscles [48]. In addition, the size of intramyocyte lipid droplets is not significantly different between both groups [48]. Thus, it does not appear that the presence of FA in the 
muscle cells is the direct cause of the appearance of insulin resistance of the tissue. FA are at the origin of the production of secondary lipid derivatives, such as diacylglycerols (DAG) and ceramides, and these species play a crucial role as mediators of the deleterious effects of FA on muscle insulin sensitivity.

\subsection{Diacylglycerols}

Diacylglycerols (DAG) are intermediate lipid species synthesized during the esterification of FA to TG, but also in the metabolism of phospholipids [49]. The transformation of DAG into TG involves diacylglycerol acyltransferases (DGAT) [50]. The DGAT1 isoform is expressed in all tissues but is highly expressed in adipose tissue, intestine, heart, and skeletal muscle [50]. The DGAT2 isoform is expressed in the liver and adipose tissue [50]. DAG are metabolic intermediates for the synthesis of specific phospholipids, in particular for the synthesis of phosphatidic acid (PA) [51]. This reaction is catalyzed by a family of DAG kinases (DGK), which phosphorylate DAG to give PA [51]. There are four isoforms of DAG kinases: $\alpha, \delta, \varepsilon$, and $\zeta$ [51].

DAG are known to be important second messengers for several metabolic processes in the cell, including transcription, cytoskeletal dynamics, release of neurotransmitters, and lipid signaling [52].

It was in hepatocytes that DAG involvement as deleterious lipids on insulin signaling was first described. In these cells, it has been demonstrated that DAG alter insulin signaling via activation of protein kinase $\mathrm{C} \varepsilon(\mathrm{PKC} \varepsilon)$ [53]. Indeed, once activated, $\mathrm{PKC} \varepsilon$ phosphorylates IRS2 on serine residues, thus preventing the propagation of the insulin signal $[13,53]$.

The involvement of DAG in hepatic insulin resistance is now well established and several studies show that a similar mechanism exists in muscle cells. Pioneer studies have shown that DAG concentrations were increased in muscles from obese and insulin-resistant rats [54]. Several studies showed that DAG activate PKC $\theta$ and phosphorylate IRS1 on its serine 307 residue, preventing the phosphorylation of IRS1 on its tyrosine residues in response to insulin, blocking insulin signaling, and thus inducing muscle cell insulin resistance (reviewed in [13]).

\subsection{Ceramides}

Ceramides are known to exert a predominant structural role, but also pro-apoptotic functions, as well as an important role in cell growth arrest, differentiation, senescence, cell migration, and cell adhesion [55]. Ceramides have a structural role within the different cell membranes. In resting cells, ceramide concentrations in the PM are very low [56]. However, these concentrations may increase rapidly in response to certain stresses (e.g., cytokines, chemotherapeutic agents) [56]. In the PM, ceramides are mainly found in lipid rafts, inducing a modification of the biophysical properties of the membrane [56]. Rafts are microdomains rich in cholesterol and sphingolipids, and they allow the compartmentalization of receptors and transporters, thus facilitating or inhibiting diverse signaling pathways [57]. These modifications of membrane structures result from the very nature of ceramides, in particular their high hydrophobicity and their high melting temperature point, which induces a decrease in their miscibility with other membrane lipids [56]. Ceramides can also modify the permeability of membranes, especially the outer membrane of mitochondria, an important step in the induction of apoptosis [58], by creating channels through the mitochondrial membrane [59].

Ceramides are second major messengers of the inflammatory response and apoptosis induced by tumor necrosis factor $\alpha(\mathrm{TNF} \alpha)$ [60]. Ceramides can also activate caspases 3 and 7 and thus promote apoptosis in erythrocytes [58].

Ceramides are also involved in some cancers. However, all species of ceramides do not play the same role in proliferation or cell death of tumor cells. For example, C16-ceramides have been shown to promote proliferation of head and neck tumor cells [61]. In contrast, C18-ceramides promote tumor growth arrest, possibly through mitophagy [61].

Ceramides are known to induce differentiation of a hematopoietic stem cell line (HL-60) [62]. They also mimic the action of a nerve growth factor on glioma cells (T9 cell line) [62]. Ceramides also 
have roles in the differentiation of skin cells. Short-chain ceramides induce differentiation in human keratinocytes [63].

In addition to those roles, ceramides are now well characterized for their inhibitory action on insulin signaling.

\section{Ceramide Metabolism and Muscle Insulin Resistance}

\subsection{Sphingolipid Biosynthesis}

Ceramides, central lipids for the biosynthesis of sphingolipids (SL), are synthesized mainly via their de novo biosynthesis pathway, almost exclusively from palmitate. In addition to this pathway, ceramides can also be synthesized via the sphingomyelinase pathway and the so-called "recycling" SL pathway.

These metabolic pathways are complex and involve several reactions taking place in different cell organelles. (i) The de novo ceramide synthesis is carried out in the endoplasmic reticulum (ER). (ii) The conversion of ceramides into complex sphingolipids such as sphingomyelins and glycosphingolipids occurs mainly in the Golgi apparatus. (iii) The recycling pathway takes place both in a lysosomal compartment and the ER.

\subsubsection{De Novo Synthesis Pathway}

This pathway starts in the ER, where four enzymes (or families of enzymes) generate ceramides of different chain lengths from a non-sphingolipid precursor (palmitate) (Figure 1). This pathway is predominant in a situation of lipid excess. Ceramide synthesis begins with the condensation of L-serine with palmitoyl-CoA by serine palmitoyl-transferase (SPT), generating 3-ketosphinganine, rapidly reduced to form sphinganine via 3-ketosphinganine reductase. Sphinganine is then acylated by ceramide synthase (CerS) isoforms to form dihydroceramide. In mammals, six CerS isoforms are expressed and are called CerS 1 to 6 [58]. They carry out the same chemical reaction but display distinct specificities for the acyl-CoA chain length they use for $\mathrm{N}$-acylation. Thus, CerS isoforms are responsible for the fatty acid composition of ceramides. The chain base moiety of the lipid is finally desaturated by dihydroceramide desaturase (DES1) at the $4-5$ position of the sphingoid base backbone to form ceramide [64].

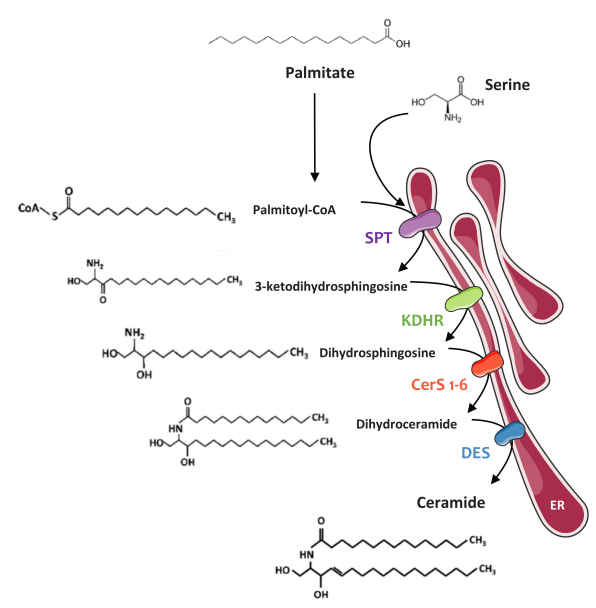

Figure 1. Ceramide de novo synthesis pathway. Palmitate is the preferential fatty acid used for the de novo synthesis of ceramides. The biosynthesis pathway takes place in the ER. Palmitoyl-CoA is first condensed with a serine to form a 3-ketodihydrosphingosine through the action of SPT. 3-Ketodihydrosphingosine is rapidly metabolized into dihydrosphingosine by KDHR. Formed dihydrosphingosine are acylated by different isoforms of CerS to form dihydroceramides of different chain lengths. Dihydroceramides are then desaturated by DES1 to give ceramides. ER: Endoplasmic reticulum; SPT: Serine palmitoyl transferase; KDHR: 3-ketodihydrosphingosine reductase; CerS: Ceramides synthases; DES1: Dihydroceramide $\Delta 4$-desaturase. 


\subsubsection{Sphingomyelinase Pathway}

Hydrolysis of SM is performed by sphingomyelinases (SMase), allowing the release of ceramides and phosphocholine [65]. There are three categories of SMases that are classified according to their optimal $\mathrm{pH}$ and their subcellular localization: acidic SMase (aSMase), neutral SMase (nSMase), and alkaline SMase. Alkaline SMase, which is only expressed in liver and intestines, plays a role in the digestion of SM from the food [65]. However, aSMase and nSMase are ubiquitously expressed and are major regulators of SM catabolism in most tissues [65].

\subsubsection{Recycling Pathway}

This pathway that takes place in lysosomes is used by complex sphingolipids that are broken down into sphingosine, which is then recycled through reacylation to produce ceramide. This pathway involves a number of key enzymes that include SMases, ceramidases, and ceramide synthases [66].

\subsection{Ceramides and Muscle Insulin Resistance}

Studies carried out both in vitro and in vivo have shown that intracellular concentrations of ceramides were increased in lipotoxic situations and contributed to the development of muscle insulin resistance (Table 1).

\subsubsection{In Vitro Studies}

A first study showed in $\mathrm{C} 2 \mathrm{C} 12$ myotubes that palmitate-induced insulin resistance implied an increase in ceramide concentrations via their de novo biosynthesis pathway, leading to the inhibition of Akt [67], a crucial kinase from the insulin signaling pathway $[18,68]$. The authors cultured C2C12 myotubes in the presence of palmitate and observed a two-fold increase in ceramide concentrations in the cells. In addition, the study showed quite similar results by directly adding short-chain C2-ceramides to the cells [67]. These results were rapidly confirmed in another cellular model of myotubes, L6 myotubes, in the presence of C2-ceramides [69]. C2-ceramide treatment induced a decrease in phosphorylation of Akt on both its serine 473 and threonine 308 residues as well as a decrease in glucose uptake and glycogen synthesis in myotubes [69].

Another study showed that inhibition of the de novo ceramide synthesis pathway partially restored insulin sensitivity of L6 myotubes [70]. Cells were incubated with palmitate in the presence or absence of myriocin, a selective inhibitor of SPT. Myriocin prevented the palmitate-induced increase of ceramides and preserved normal activation of both Akt and glucose transport in response to insulin [70].

\subsubsection{In Vivo Studies}

Many in vivo studies have confirmed the major role of ceramides in the installation of muscle insulin resistance observed in vitro (Table 1).

It has been known since the early 1990s that ceramide concentrations are increased in both soleus and plantaris muscles of obese and diabetic Zucker rats [54]. Since then, several groups have used pharmacological approaches to highlight the importance of ceramides in the development of muscle resistance in vivo.

A study conducted in mice fed a high-fat diet and treated with myriocin demonstrated that inhibition of ceramide synthesis was sufficient to partially restore insulin-stimulated Akt phosphorylation in gastrocnemius muscles [26]. This improvement in muscle Akt phosphorylation was accompanied by better glucose tolerance and insulin sensitivity [26]. 
Table 1. Analysis of the relationship between muscle ceramide levels and insulin resistance. BMI: body mass index; C2-cer: C2-ceramides; C6-cer: C6-ceramides; Cer: ceramides; DES1: dihydroceramide desaturase 1; NGT: normal glucose tolerant; IGT: Impaired glucose tolerant; HFD: high fat diet; Pal: palmitate; SPT: serine palmitoyl transferase; T2D: type 2 diabetes; [ ]: concentration; ND: not described.

\begin{tabular}{|c|c|c|c|c|c|}
\hline First Author (Year) & Ref. & Model (Vitro) & Intervention & Ceramide Content & Change in Insulin Resistance \\
\hline Schmitz-Peiffer (1999) & [67] & C2C12 myotubes & Pal / C2-cer & $\nearrow$ [total Cer] & $\nearrow$ \\
\hline Hajduch (2001) & [69] & L6 myotubes & C2-cer & $\mathrm{ND}$ & $\nearrow$ \\
\hline \multirow{2}{*}{ Cazzolli (2001) } & \multirow{2}{*}{ [71] } & \multirow{2}{*}{$\mathrm{C} 2 \mathrm{C} 12$ myotubes } & $\mathrm{Pal}$ & \multirow{2}{*}{ ND } & $\nearrow$ \\
\hline & & & Pal + PP2A inhibition & & $\searrow$ \\
\hline \multirow{2}{*}{ Bourbon (2002) } & \multirow{2}{*}{ [72] } & \multirow{2}{*}{ Smooth muscles cells (a7r5) } & C2-cer / C6-cer & ND & $\nearrow$ \\
\hline & & & 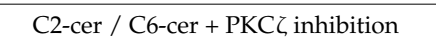 & ND & $\searrow$ \\
\hline Chavez (2003) & [73] & $\mathrm{C} 2 \mathrm{C} 12$ myotubes & Pal & $\nearrow[$ long chain Cer, total Cer] & $\nearrow$ \\
\hline \multirow{2}{*}{ Powell (2003) } & \multirow{2}{*}{ [74] } & \multirow{2}{*}{ L6 myotubes } & C2-cer & $\mathrm{ND}$ & $\nearrow$ \\
\hline & & & C2-cer + PKC $\zeta$ inhibition & ND & $\searrow$ \\
\hline \multirow{3}{*}{ Powell (2004) } & \multirow{3}{*}{ [75] } & \multirow{3}{*}{ L6 myotubes } & Pal / C2-cer & $\nearrow[$ total Cer] & $\nearrow$ \\
\hline & & & Pal / C2-cer + SPT inhibition & $\searrow$ [total Cer] & $\searrow$ \\
\hline & & & Pal/C2-cer + PP2A/PKC $\zeta$ inhibition & $\mathrm{ND}$ & $\searrow$ \\
\hline \multirow{2}{*}{ Hajduch (2008) } & \multirow{2}{*}{ [76] } & \multirow{2}{*}{ L6 myotubes } & C2-cer & ND & $\nearrow$ \\
\hline & & & C2-cer + PKC C inhibition & ND & $\searrow$ \\
\hline \multirow{2}{*}{ Watson (2009) } & \multirow{2}{*}{ [70] } & \multirow{2}{*}{ L6 myotubes } & $\mathrm{Pal}$ & $\nearrow[$ total Cer] & $\nearrow$ \\
\hline & & & Pal + SPT inhibition & $\searrow$ [total Cer] & $\searrow$ \\
\hline \multirow{2}{*}{ Frangioudakis (2013) } & \multirow{2}{*}{ [77] } & \multirow{2}{*}{ L6 myotubes } & $\mathrm{Pal}+\mathrm{CerS}(1,2,4,5,6)$ overexpression & $\nearrow$ [some species] depending on CerS overexpressed & $\searrow$ \\
\hline & & & Pal + CerS $(1,2,4,5,6)$ knockdown & $\searrow$ [some species] depending on CerS Knockdowned & No effect on insulin signaling \\
\hline \multirow{4}{*}{ Mahfouz (2014) } & \multirow{4}{*}{ [78] } & \multirow{2}{*}{ C2C12 myotubes / L6 myotubes } & $\mathrm{Pal} / \mathrm{C} 2$-cer & ND & $\nearrow$ \\
\hline & & & $\mathrm{Pal} / \mathrm{C} 2$-cer + PP2A/PKC $\zeta$ inhibition & ND & $\searrow$ \\
\hline & & \multirow{2}{*}{ Human myotubes } & Pal & $\nearrow[\mathrm{C} 16: 0, \mathrm{C} 18: 0, \mathrm{C} 20: 0]$ & $\nearrow$ \\
\hline & & & Pal + SPT inhibition & $\searrow[\mathrm{C} 16: 0, \mathrm{C} 18: 0, \mathrm{C} 20: 0]$ & $\searrow$ \\
\hline \multirow{4}{*}{ Hage Hassan (2016) } & \multirow{4}{*}{ [79] } & \multirow{2}{*}{$\mathrm{C} 2 \mathrm{C} 12$ myotubes } & Pal / C2-cer & $\nearrow$ [total Cer] when Pal / ND when C2-cer & $\nearrow$ \\
\hline & & & Pal / C2-cer + SPT inhibition & $\searrow$ [total Cer] when Pal / ND when C2-cer & $\searrow$ \\
\hline & & \multirow{2}{*}{ Human myotubes } & Pal & ND & $\nearrow$ \\
\hline & & & $\mathrm{Pal}+\mathrm{PKR}$ inhibition & ND & $\searrow$ \\
\hline \multirow{2}{*}{ Bandet (2018) } & \multirow{2}{*}{ [80] } & $\mathrm{C} 2 \mathrm{C} 12$ & Pal & $\nearrow$ [total Cer] & $\nearrow$ \\
\hline & & & Pal + SPT inhibition & $\searrow[$ total Cer] & $\searrow$ \\
\hline
\end{tabular}


Table 1. Cont.

\begin{tabular}{|c|c|c|c|c|c|}
\hline First Author (Year) & Ref. & Model (Vitro) & Intervention & Ceramide Content & Change in Insulin Resistance \\
\hline \multirow{2}{*}{ Pillon (2018) } & \multirow{2}{*}{ [81] } & \multirow{2}{*}{ L6 myotubes } & Pal & $\nearrow[$ total Cer] & $\nearrow$ \\
\hline & & & Pal + SPT / CerS inhibition & $\searrow$ [total Cer] & No effect on insulin signaling \\
\hline Huang (2016) & [82] & $\mathrm{C} 2 \mathrm{C} 12$ myotubes & Lipin-1 inhibition & $\nearrow[\mathrm{C} 16: 0, \mathrm{C} 22: 0, \mathrm{C} 24: 0]$ & $\nearrow$ \\
\hline First Author (Year) & Ref. & Model (Rodents) & Intervention & Muscle Ceramide Content & Change in Insulin Resistance \\
\hline Turinsky (1990) & [54] & Zucker rats & 1 & $\nearrow[$ total Cer $]$ & $\nearrow$ \\
\hline \multirow{4}{*}{ Holland (2007) } & \multirow{4}{*}{ [83] } & Mice & DES1 haploinsufficiency & $\searrow$ [total Cer] & $\searrow$ \\
\hline & & \multirow{2}{*}{ Rats } & Dexamethasone + SPT inhibition & ND & $\searrow$ \\
\hline & & & Lipids infusion + SPT inhibition & $\searrow$ [total Cer] & $\searrow$ \\
\hline & & Zucker rats & SPT inhibition & $\searrow_{\text {[total Cer] }}$ & $\searrow$ \\
\hline \multirow{2}{*}{ Ussher (2010) } & \multirow{2}{*}{ [26] } & \multirow{2}{*}{ Mice } & HFD & $\nearrow[$ total Cer] & $\nearrow$ \\
\hline & & & HFD + SPT inhibition & $\searrow$ [total Cer] & $\searrow$ \\
\hline Turner (2013) & [84] & Mice & HFD & 3weeks: $\nearrow[C 18: 0] ; 16 w e e k s: ~ \nearrow[C 16: 0, \mathrm{C} 18: 0]$ & $\nearrow$ \\
\hline \multirow{2}{*}{$\begin{array}{l}\text { Blachnio-Zabielska } \\
\quad(2016)\end{array}$} & \multirow{2}{*}{ [85] } & \multirow{2}{*}{ Rats } & HFD & $\nearrow[C 14: 0$, C18:0, C18:1, C24:1, C24:0, total Cer] & $\nearrow$ \\
\hline & & & HFD + SPT inhibition & $\searrow[\mathrm{C} 16: 0, \mathrm{C} 18: 0, \mathrm{C} 18: 1, \mathrm{C} 20: 0$, total Cer] & $\searrow$ \\
\hline \multirow{2}{*}{ Hage Hassan (2016) } & \multirow{2}{*}{ [79] } & \multirow{2}{*}{ Mice } & HFD & ND & $\nearrow$ \\
\hline & & & HFD + SPT inhibition & ND & $\searrow$ \\
\hline Turner (2018) & [86] & Mice & HFD + CerS1 inhibition & $\searrow[\mathrm{C} 18: 0, \mathrm{C} 18: 1] ; \nearrow[\mathrm{C} 22: 0, \mathrm{C} 24: 0, \mathrm{C} 24: 1$, total Cer $]$ & $\nearrow$ \\
\hline \multirow{2}{*}{ Bandet (2018) } & \multirow{2}{*}{ [80] } & \multirow{2}{*}{ Mice } & HFD & $\nearrow[$ total Cer] & $\nearrow$ \\
\hline & & & HFD + CERT overexpression & $\searrow[C 16: 0$, C22:0, C24:0, C24:1] & $\searrow$ \\
\hline \multirow{3}{*}{ Turpin-Nolan (2019) } & \multirow{3}{*}{ [87] } & \multirow{3}{*}{ Mice } & HFD & $\nearrow[\mathrm{C} 14: 0, \mathrm{C} 18: 0] ; \searrow[\mathrm{C} 26: 0]$ & $\nearrow$ \\
\hline & & & HFD + CerS1 KO & $\nearrow[C 16: 0$, C22:0, C22:1, C24:0, C24:1] \ $\searrow[C 18: 0]$ & $\searrow$ \\
\hline & & & HFD + CerS1 KO muscle specific & $\nearrow[\mathrm{C} 22: 1, \mathrm{C} 24: 0, \mathrm{C} 24: 1] ; \searrow[\mathrm{C} 18: 0, \mathrm{C} 18: 1, \mathrm{C} 22: 0]$ & $\searrow$ \\
\hline First Author (Year) & Ref. & Model (Human) & Intervention & Muscle Ceramide Content & Change in Insulin Resistance \\
\hline Adams (2004) & [88] & Lean $(n=10)$ and obese $(n=10)$ & / & $\begin{array}{c}\nearrow[\mathrm{C} 16: 0, \mathrm{C} 18: 0, \mathrm{C} 20: 0, \mathrm{C} 22: 0, \mathrm{C} 24: 0, \mathrm{C} 24: 1, \text { total Cer] } \\
\text { compared to lean }\end{array}$ & $\begin{array}{l}\nearrow(\text { total and in muscle) in obese } \\
\text { compared to lean }\end{array}$ \\
\hline Straczkowski (2007) & [89] & $\begin{array}{l}\text { Lean }(n=12) \text {, NGT }(n=12) \text { or IGT } \\
(n=9) \text { obese, healthy offspring of } \\
\text { T2D people }(n=12)\end{array}$ & / & $\begin{array}{l}\nearrow \text { [total Cer] in offspring and IGT obese compared to } \\
\text { lean; } \nearrow \text { [total Cer] in ITG obese compared to others }\end{array}$ & ND \\
\hline Coen (2010) & [90] & $\begin{array}{l}\text { Women obese insulin resistant }(n= \\
\text { 12) or insulin sensitive }(n=10)\end{array}$ & / & $\begin{array}{c}\nearrow[\mathrm{C} 14: 0, \mathrm{C} 16: 0, \mathrm{C} 18: 0, \text { total Cer, saturated Cer, } \\
\text { unsaturated Cer] }\end{array}$ & $\begin{array}{c}\nearrow \text { in insulin resistant obese } \\
\text { compared to insulin sensitive obese }\end{array}$ \\
\hline Amati (2011) & [48] & $\begin{array}{c}\text { Lean }(n=7) \text {, athletes }(n=14) \text {, IGT } \\
\text { obese }(n=21)\end{array}$ & / & $\nearrow[\mathrm{C} 18: 1, \mathrm{C} 24: 0, \mathrm{C} 24: 1$, total $] ; \searrow[\mathrm{C} 14: 0]$ & $\begin{array}{c}\nearrow \text { in obese compared to others; } \searrow \\
\text { in athletes compared to others }\end{array}$ \\
\hline Coen (2013) & [91] & $\begin{array}{c}\text { Women lean }(n=8) \text { or obese }(2 \\
\text { groups: } 30<\text { BMI }<34,9(n=7) \text { and } \\
\text { BMI }>35(n=15))\end{array}$ & / & $\begin{array}{c}\nearrow[\mathrm{C14}: 0, \mathrm{C} 20: 1, \mathrm{C} 22: 1, \mathrm{C} 24: 0, \mathrm{C} 24: 1] \text { in the two } \\
\text { groups of obese }\end{array}$ & $\begin{array}{c}\nearrow \text { in obese }(30<\text { BMI }<34.9) \\
\text { compared to lean; } \nearrow \text { in obese } \\
(\mathrm{BMI}>35) \text { to others }\end{array}$ \\
\hline
\end{tabular}


Table 1. Cont

\begin{tabular}{|c|c|c|c|c|c|}
\hline First Author (Year) & Ref. & Model (Human) & Intervention & Muscle Ceramide Content & Change in Insulin Resistance \\
\hline Bergman (2016) & [92] & $\begin{array}{c}\text { Obeses }(n=14) / \mathrm{T} 2 \mathrm{D}(n=15) / \\
\text { athletes }(n=15)\end{array}$ & I & $\begin{array}{c}\nearrow[\mathrm{C} 18: 0] \text { in T2D vs obese and athletes; } \nearrow[\mathrm{C} 24: 0] \text { in } \\
\text { athletes vs obese and T2D }\end{array}$ & $\begin{array}{c}\searrow \text { in muscle of athletes compared to } \\
\text { others; }\end{array}$ \\
\hline Broskey (2018) & [93] & $\begin{array}{l}\text { Obese without T2D }(n=62) \text { and } \\
\quad \text { obese with T2D }(n=44)\end{array}$ & / & $\nearrow[$ [C18:1, C20:0, C22:0, C24:0, C24:1 total Cer] & $\begin{array}{c}\nearrow \text { in obese with T2D compared to } \\
\text { obese without T2D }\end{array}$ \\
\hline Perreault (2018) & [94] & $\begin{array}{c}\text { Lean }(n=15) / \text { athletes }(n=16) / \\
\text { obese without T2D }(n=15) / \text { obese } \\
\text { with T2D }(n=12)\end{array}$ & / & $\begin{array}{c}\nearrow[\text { Cer total] in total muscle of T2D compared to } \\
\text { others; } \nearrow[\mathrm{C} 16: 0, \mathrm{C} 18: 0, \text { Cer total] in sarcolemma of } \\
\text { T2D compared to others; } \nearrow[\mathrm{C} 18: 0 \text {, Cer total] in } \\
\text { nucleus of T2D compared to others }\end{array}$ & $\begin{array}{l}\nearrow \text { in T2D compared to others; } \nearrow \text { in } \\
\text { obese compared to lean and athletes }\end{array}$ \\
\hline
\end{tabular}


These data were rapidly confirmed by a study showing that inhibition of ceramide synthesis could counteract glucocorticoid-induced insulin resistance [83]. Rats treated with dexamethasone, a synthetic glucocorticoid, displayed impaired glucose metabolism and insulin resistance [83]. However, treatment of these animals with myriocin restored their glucose tolerance and insulin sensitivity [83]. In the same study, authors also showed that treatment of obese Zucker rats with myriocin significantly improved their glucose tolerance and decreased their blood glucose, as a result of a decrease in plasma and tissue ceramide concentrations [83].

They also used a genetic approach to confirm the role of ceramides in insulin resistance in vivo. The authors generated DES1 knock-out (KO) mice (DES -/+). A decrease in ceramide concentrations in several tissues (heart, liver, brown adipose tissue, and soleus muscle) was observed in dexamethasone-treated mice compared to ceramide concentrations observed in wild-type mice. An increase in insulin sensitivity was observed in the DES1 KO animals compared to their wild-type littermates [83].

More recently, a study in rats fed a high-fat diet showed that myriocin treatment also helped normalizing glucose tolerance and insulin sensitivity [85]. This treatment induced a decrease in ceramide concentrations in soleus muscle [85]. Restoration of insulin-stimulated Akt phosphorylation was also observed in soleus muscle of myriocin-treated rats [85].

\subsubsection{Human Studies}

As in obese rodent models, several studies showed that muscle ceramide concentrations were increased in obese and insulin-resistant patients compared to healthy individuals (Table 1).

A study conducted in obese and lean subjects showed a strong correlation between loss of insulin sensitivity and increased intramuscular ceramide concentrations [88]. These results suggest that high muscle concentration of ceramides of obese individuals contribute to insulin resistance.

Similar results have been described in other studies. Total ceramide concentrations were shown to be increased in vastus lateralis muscles of obese subjects compared to those of lean subjects [89]. Several other studies show results similar to those previously described $[48,90,91]$.

Interestingly, C16- to C24-ceramide species have been shown to be the most associated with hyperinsulinemia and a strong HOMA-IR (homeostasis model assessment of insulin resistance, a test to measure the $\beta$-cell function and insulin sensitivity) $[93,95]$.

\section{Mechanisms of Ceramide-Mediated Muscle Insulin Resistance}

Given the major role that ceramides exert on the regulation of muscle insulin sensitivity, it was legitimate to question their mode of action within cells, and ceramides have been demonstrated to target two major players in insulin signaling: Akt via two different mechanisms, and IRS1.

\subsection{Inhibition of Akt by Ceramides}

Pioneering studies showed that the phosphatase PP2A mediated Akt inhibition by ceramides in $\mathrm{C} 2 \mathrm{C} 12$ myotubes. When cultured in the presence of palmitate, an increase in PP2A activity and a concomitant decrease in the activity and phosphorylation of Akt in response to insulin was observed $[71,73,96]$. Inhibition of PP2A activity (with the PP2A inhibitor okadaic acid) completely restored insulin-induced Akt phosphorylation, thus confirming the role of PP2A in the inhibition of insulin signaling in this muscle cell model $[71,73,96]$ (Figure 2). 


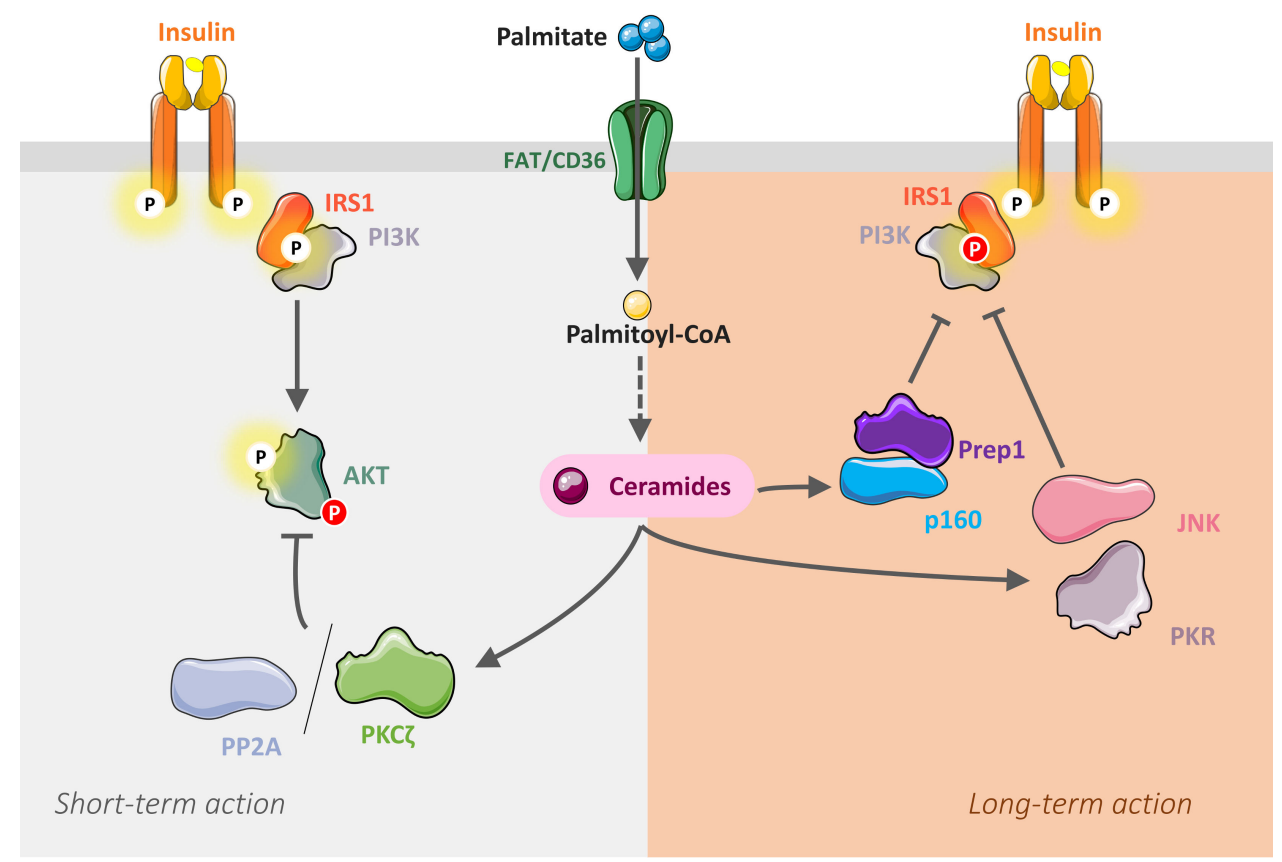

Figure 2. Short- and long-term action of ceramides on insulin signaling in muscle cells. Ceramides inhibit the insulin signaling pathway in muscle cells by targeting in a time-dependent manner two important actors, Akt and IRS1. Ceramides rapidly activate either PP2A or PKC $\zeta$ to inactivate Akt. In the long-term, ceramides induce PKR/JNK and/or Prep1-p160 axes to target IRS1. IRS1: Insulin receptor substrate 1; JNK: c-Jun NH2-terminal kinase; PI3K: Phosphoinositide-3-kinase; PKC C: Protein kinase C $\zeta$; PKR: Double stranded ARN-activated protein kinase; PP2A: Protein phosphatase 2A. Prep1: $\mathrm{Pbx}$ regulating protein 1 . Dotted arrows: indirect action; Solid arrows: direct action. P: phosphorylation.

A second mechanism, independent of PP2A, but implicating the atypical protein kinase $\mathrm{C} \zeta$ (PKC C), has been highlighted in another muscle cell line (myotubes L6) [97], in human muscle cells [78], and in adipocytes [76] (Figure 2). This second mechanism involved a loss in membrane recruitment and phosphorylation of Akt by a process dependent on activation of PKC $\zeta[72,74,75]$. PKC $\zeta$ has been described to directly interact with and to repress the activity of Akt in several cell types [72,74,98-100], but to dissociate upon cell treatment with growth factors [98] and insulin [99], thereby allowing Akt to become activated. However, when intracellular ceramide contents are increased, a potent activation of PKC $\zeta$ is observed [69,70], stabilizing the interaction between Akt and PKC $\zeta$ [74]. This interaction antagonizes the ability of insulin to dissociate the kinase complex, but also to activate Akt [74] (Figure 2). Interestingly, involvement of PM microdomains called caveolae has been demonstrated in this mechanism. Caveolae are specific sites for ceramide production in response to various stresses [101]. They are small invaginations of the PM enriched in cholesterol and SL, and proteins called caveolins are very important for the formation and stability of these structures [101,102]. These caveolae are found in many cell types but are very abundant in insulin-sensitive cells such as adipocytes and muscle cells [101]. The presence of PKC $\zeta$ in these caveolae, as well as its interaction with caveolins, has also been highlighted [103], and our laboratory showed that ceramides induced the recruitment and sequestration of both Akt and PKC $\zeta$ in these microdomains, thus blocking the insulin signal [76].

Considering all these data, one question remained unresolved: why did ceramides inactivate Akt via two independent mechanisms, PP2A or PKC $\zeta$ ? Studies in our laboratory demonstrated that, in caveolae-poor cells (C2C12 myotubes, fibroblasts), ceramides act via PP2A on insulin signaling, whereas a PKC $\zeta$-dependent mechanism is taking place in caveolae-rich cells (adipocytes, L6 and human myotubes) $[78,104]$. 


\subsection{Inhibition of IRS1 by Ceramides}

In vivo, in rodents fed a high fat diet, skeletal muscle insulin resistance was observed usually at the level of both IRS1 and Akt [105-107]. However, although the mechanisms by which ceramides inhibited Akt were well demonstrated (see previous chapter), those involved a possible inhibition of IRS1 remained unclear until recently.

Hage Hassan et al. showed that long-term incubation of C2C12 myotubes with palmitate induced IRS1 phosphorylation on serine residue, thus preventing IRS1 activation in response to insulin [79]. Similar effects were obtained by chronically incubating myotubes directly with C2-ceramides [79]. They showed that this mechanism implied the double-stranded RNA-activated protein kinase (PKR), a protein involved in the innate immune response [79]. At the time, PKR was already known to modulate negatively both IRS1 and IRS2 in a hepatic tumor cell line, and to modulate negatively insulin sensitivity in a model of obese mice fed a fat diet [108-110]. Hage Hassan et al. demonstrated that PKR was activated in vitro in muscle cell lines treated with palmitate or directly with ceramides, in vivo in muscles obtained from high-fat diet fed mice and from genetically obese mice, and also in human diabetic patient muscle cells [79]. They showed that long-term ceramide activation of PKR inhibited insulin-induced IRS1 activation in muscle cells in a JNK dependent manner [79]. Preventing ceramide-induced PKR or JNK activation restored muscle cell insulin sensitivity [79].

Interestingly, IRS1 has also been shown to be a target for ceramide-induced transcription factors Prep1 (Pbx regulating protein 1) and p160 in muscle cells [111]. Prep1 is a physiologic regulator of insulin-mediated glucose and lipid metabolism in skeletal muscle [112,113]. In muscle, Prep1 binds and stabilizes p160, thus repressing GLUT4 expression [112]. A recent study demonstrated that long-term ceramide action promoted Prep1-p160 association and impaired insulin-induced IRS1 phosphorylation in muscle cells [111].

Overall, in muscle cells, ceramides inhibit insulin signaling via two mechanisms: a short-term mechanism directed towards Akt through the activation of PP2A/PKC $\zeta$ pathways; and longer-term mechanisms involving PKR/JNK and/or Prep1-p160 axes that target IRS1 (Figure 2).

\subsection{Importance of Ceramide Species in the Onset of Muscle Insulin Resistance}

Ceramide is not a homogeneous lipid class since several species with different chain lengths (from C14 to C26) exist. This is why more and more studies are interested in the role of these different species in the development of insulin resistance.

In hepatocytes, for example, studies suggest that C16-ceramides play an important role in the development of insulin resistance [114-116] whereas C22-, C24: 1, and C24-ceramides are protective [115].

In muscle cells, no specific ceramide species have been confidently identified so far, but C18-ceramides have been often cited as potential candidates. Several studies have shown a positive correlation between muscle C18-ceramide content and insulin resistance $[84,85,92,117]$. In addition, a recent study found that $\mathrm{C} 18$-ceramides concentrations were increased at the level of the PM in muscle cells of T2D individuals [94]. It is important to note that these studies showed positive correlations between C18-ceramide concentrations and insulin resistance, and not causes to effect action. However, a very recent study filled this gap and highlighted a functional implication of C18-ceramide species in the pathogenesis of insulin resistance [87]. Brüning's lab demonstrated that global or muscle specific reduction of C18-ceramide content enhanced whole-body glucose metabolism [87]. Thus, these results revealed the tissue-specificity function of $\mathrm{C} 18$-ceramides during the development of obesity associated insulin resistance.

Nevertheless, a no less interesting and recent study showed conflicting data and demonstrated that the implication of C18-ceramides in the development of muscle insulin resistance was not that undisputable. Turner et al., developed a specific inhibitor of CerS1 (PO53), leading to a decrease in C18-ceramide concentrations $(-50 \%)$ in the skeletal muscles of mice subjected to a high-fat diet [86]. Despite this decrease in intramuscular C18-ceramide concentrations, both the glucose tolerance 
and insulin sensitivity were not improved [86]. This suggests that C18-ceramides are not a main lipid actor for the development of insulin resistance in these animals or that the remaining muscle C18-ceramide content is enough to inhibit muscle insulin sensitivity. On the other hand, the authors of this paper showed that $\mathrm{C} 18$-ceramides played a very important role in fat storage by inhibiting mitochondrial $\beta$-oxidation [86]. Another recent study tended to lead to the same conclusion. Bandet et al. overexpressed the ceramide transporter CERT that transports newly synthetized ceramides from the endoplasmic reticulum towards the Golgi apparatus to be transformed into SM in tibialis anterior muscle from mice fed a high-fat diet [80]. Only concentrations of some ceramide species were impacted by CERT overexpression. They observed a decrease in concentrations of C16-, C22-, C24:1-, and C24-ceramide species in CERT overexpressing tibialis anterior muscles compared to control muscles, without any change in both C18- and C20-ceramide species [80]. It seems that the responsibility for insulin resistance is rather to be sought from the other ceramide species that vary in this study (C16, C22, C24:1, and C24) [80].

\section{Ceramide vs DAG as Modulators of Muscle Insulin Sensitivity}

Although many studies have found DAG to alter the insulin response in muscle cells, some other studies do not report such effects. A non-exhaustive list of them are presented below.

Selathurai et al. used a mouse model in which the gene encoding to phosphoethanolamine cytidylyltransferase, an enzyme that metabolizes DAG and ethanolamine to form phosphoethanolamine, was specifically invalidated in muscles [118]. A two-fold increase in DAG concentrations of mouse muscle cells was observed without inducing insulin resistance [118].

Other studies show similar results. Indeed, an increase in muscle glucose uptake and insulin sensitivity was observed in mice in which muscle DAG concentrations were increased after overexpression of DGAT1 in the mouse tibialis anterior [119]. Mice fed a high-fat diet (45\% fat) were treated with a $\beta$-oxidation inhibitor (etomoxir), thus leading to an intracellular accumulation of lipids, and in particular, DAG in the anterior tibialis anterior of the animals [120]. Insulin sensitivity was found to be improved in these muscles [120], and mice treated with the inhibitor were more glucose-tolerant than the placebo-treated mice [120].

Studies performed in humans did not report any differences in DAG concentrations in obese T2D patient myotubes compared to control subjects [47,91]. Additional studies reported identical results in obese and glucose-tolerant individuals compared to obese and glucose-intolerant individuals [90,121], and it has even been shown that muscle DAG concentrations of obese and T2D individuals were lower than those of healthy individuals [122].

Despite the important literature linking ceramides and muscle insulin resistance, there are also some studies that did not report this causal link.

Several studies have shown that DAG are responsible for muscle insulin resistance observed in response to lipid perfusion in rats [123], in healthy human subjects [124] or in obese subjects [125], without any modification of ceramide concentrations being reported. This would suggest that ceramides did not interfere in the development of muscle insulin resistance under these particular lipotoxic conditions. It should be noted, however, that all the studies reporting a lack of ceramide effects used a lipid infusion approach, both in mice and humans, and that the lipid exposure time course remained rather short (from 1 to $9 \mathrm{~h}$ ) [123-125]. One possible explanation could be that the time exposure of tissues to the lipids was not sufficient to produce enough ceramides (or at least to produce the deleterious ceramide species) since it has been shown in vitro that at least a $16 \mathrm{~h}$ exposure of muscle cells with palmitate was necessary to synthetize enough endogenous ceramides $[67,70,73,75,126]$. Therefore, it is conceivable that DAG are produced in a very short period of time (less than $9 \mathrm{~h}$ ) and thus, they act primarily on the insulin signaling pathway, ceramides taking over later on. Further studies will surely be needed to answer these questions.

Another study tried to demonstrate that muscle ceramide species were not implicated in the generation of insulin resistance [77]. CerS isoforms were overexpressed using adenovirus or knocked 
down using siRNAs in L6 muscle cells. Unexpectedly, they observed that overexpression of some CerS isoforms promoted insulin action, without any negative effect on insulin sensitivity [77]. These results were found peculiar at the time but could be explained by the very low palmitate concentrations used in the study. At that lipid concentration, no loss in insulin signal (on both IRS Akt phosphorylation), or action (on glycogen synthesis) were observed [77].

A very recent in vitro study from Klip's lab also suggested that muscle ceramide accumulation did not play a causative role in the development of insulin resistance [81]. Using various inhibitors of the ceramide de novo biosynthesis pathway, they failed to see an improvement in palmitate-induced insulin resistance in L6 muscle cells [81]. These results were opposite from those obtained in the same cell line and published earlier by Powell et al. [75]. These discrepancies, however, could be explained by very important differences in palmitate response between the two studies. Pillon et al. observed only a 10 to $20 \%$ increase in intracellular ceramide content in response to palmitate [81]. In contrast, Powell et al. saw a 6-fold increase in total ceramide concentrations upon palmitate treatment in the same cells [75]. Since an increase in DAG content was also observed in these conditions [75], it is conceivable that, in the lipotoxic model used by Pillon et al. (low ceramide concentration in response to palmitate), development of insulin resistance became DAG dependent.

DAG or ceramides are both lipids that play important roles in establishing muscle insulin resistance. As stated above, it is therefore difficult to identify which class of lipids exerts the most determining role. Nevertheless, some studies showed that ceramides have more influence than DAG on the development of muscle insulin resistance.

This has been demonstrated in an in vitro study in which L6 myotubes were cultured in the presence of both palmitate and myriocin. A restoration of insulin-stimulated Akt phosphorylation, despite an increase in DAG concentrations, was observed [70]. The dominance of ceramide influence versus DAG in muscle cells was confirmed in a recent study showing that lipin-1 silencing impaired insulin sensitivity in C2C12 myotubes [82]. Interestingly, the authors observed decreased intracellular DAG levels and increased ceramide accumulation in these cells [82].

Similar results were demonstrated in muscles from mice fed a high-fat diet and treated or not with myriocin. In animals treated with myriocin, muscle insulin sensitivity was improved, despite an increase in muscle DAG concentrations [26]. Comparable observations were made with equivalent protocols in rats $[70,83]$.

Several studies carried out in humans showed similar results to those observed in vitro, or in animals. Ceramide concentrations were found to be increased in muscles from obese and insulin-resistant individuals compared to obese, but insulin-sensitive patients, whereas muscle DAG concentrations were unchanged $[89,121]$. In addition, ceramide concentrations were found to be increased in muscles of obese individuals with T2D compared to those observed in athletes highly sensitive to insulin $[48,94]$, whereas muscle DAG concentrations were twice as large in muscles from athletic individuals compared to obese and diabetic subjects [48].

In conclusion, it seems that ceramides are the lipid species playing a determining role in the establishment of muscle insulin resistance, while the influence of DAG appears to be less crucial in this tissue.

\section{Ceramide Lipid Derivatives and Muscle Insulin Resistance}

Sphingolipid derivatives synthesized from ceramides have also been shown to modulate insulin signaling in muscle cells.

\subsection{Ceramide-1-phosphate}

One study showed in a mouse model that the total invalidation of ceramide kinase (CERK), a kinase responsible for the formation of ceramide-1-phosphate from ceramide, protected animals from obesity and glucose intolerance induced by a fat diet [127]. In addition, CERK knockout also protected mouse adipose tissue from macrophage infiltration, thus preventing adipose tissue inflammation [127]. 


\subsection{Sphingosine-1-phosphate}

In order to give sphingosine-1-phosphate (S1P), ceramides are first deacylated by the action of ceramidases to produce sphingosine [65]. The latter can then be phosphorylated with sphingosine kinase (SphK) to form S1P [65]. There are two isoforms of SphK, SphK1, and SphK2. They catalyze the same reaction, but their subcellular localization is different. SphK1 is mainly cytosolic, whereas SphK2 is localized in the different cellular compartments, like the nucleus [128].

Several studies have investigated the link between S1P and insulin sensitivity. This interest is explained by the fact that S1P exerts opposite effects to those of ceramides on growth and cell survival [128]. Thus, it is conceivable that its action on insulin sensitivity could also oppose that of ceramides. However, there is no real consensus regarding the role of S1P on the regulation of insulin sensitivity. Some studies give to $\mathrm{S} 1 \mathrm{P}$ a protective role while others report it as a contributor to insulin resistance [129].

\subsection{Complex Sphingolipids: Sphingomyelin and Glucosylceramides}

Ceramides are synthetized in the ER and need to be transported towards the Golgi apparatus to be metabolized into complex sphingolipids. Two types of ceramide transport exist, vesicular and non-vesicular transport $[65,130]$.

Vesicular transport allows transport of ceramides from the ER to the cis Golgi network, independently of ATP. These ceramides will be metabolized into glucosylceramides (GlcCer). This transport has not been well described but is PI3K dependent [131].

The non-vesicular transport allows the trafficking of ceramides from the ER to the trans Golgi network, where ceramides are metabolized into sphingomyelin (SM). The transporter, called CERT (for ceramide transporter), works in an ATP-dependent manner [130]. CERT is part of the family of proteins containing a START (steroidogenic acute regulatory protein-related lipid transfer) domain [132]. The START domain is well conserved during evolution and is found both in plant and animal cells [132]. CERT is also known as STARD11 [132].

\subsubsection{Glucosylceramides}

GlcCer are synthesized from ceramides and UDP-glucose. This reaction is catalyzed by the GlcCer synthase, localized in the cis Golgi [65]. There are hundreds of species of GlcCer [133], some being surely essential for the development of mammals since mice invalidated for the gene encoding GlcCer synthase died at the embryonic stage [65]. GlcCer serve as precursors for synthesis of gangliosides [65], after the addition of a galactose residue to give a lactosylceramide [133]. This lactosylceramide will subsequently be metabolized into monosialodihexosylganglioside (GM3) through the action of GM3 synthase [134]. GM3 will serve as a precursor for the synthesis of various other gangliosides in the cell [134].

GlcCer inhibit insulin signaling in C2C12 myotubes, independently of ceramides [135].

Most studies reporting effects of GlcCer on insulin sensitivity focused primarily on the action of GM3. The first study reporting an effect of this lipid showed that mice invalidated for GM3 synthase exhibited better glucose tolerance, even when they were fed a high-fat diet [134]. In addition, phosphorylation of IR was greater in GM3 synthase knockout mouse muscles [134].

Another study reported that inhibition of GlcCer synthesis in vivo improved blood glucose levels and insulin sensitivity in a diabetic mouse model [136]. Mechanisms that may explain the negative role of GM3 on insulin signaling have been studied in 3T3-L1 adipocytes [137] and human embryonic kidney cells (HEK 293) [138]. It has been demonstrated that, in the PM, IR was associated with caveolin 1, and that the increase in GM3 concentrations promoted the dissociation of this complex, thus inhibiting propagation of the insulin signal. 


\subsubsection{Sphingomyelin}

Once in the trans Golgi, ceramides are metabolized into SM through the action of sphingomyelin synthase (SMS) [65]. SM are the most abundant complex SL in mammalian cells [65]. Two SMS isoforms are expressed in cells, SMS1 and SMS2. SMS1 is localized in the Golgi apparatus, whereas SMS2 is mainly located in the PM [65]. SMS carry out the transfer of a phosphocholine group from phosphatidylcholine onto ceramides. This reaction releases a SM, but also a DAG [65].

A metabolomic study demonstrated that reduced levels of plasma C16:1-SM species were predictive of T2D [139]. Inhibition of SMS in muscle cells induced a rise in ceramide content and impaired insulin signaling [140]. In addition, obese and glucose intolerant individuals showed an increased muscle ceramide content and lower muscle SM compared to obese and normal glucose tolerant individuals [89]. Altogether, it seems that the transformation of ceramides into SM could be a way to prevent ceramides from accumulating in cells and thus to overcome their deleterious effect on insulin signaling.

A recent study performed in the lab went in that direction. Bandet et al. showed that increased concentrations of ceramides in response to saturated FA were associated with a defective transport of ceramides from the ER to the Golgi apparatus in muscle cells [80]. Overexpression of CERT in vitro in muscle cells under lipotoxic conditions or in vivo in the anterior tibialis muscle of mice fed a high-fat diet improved insulin sensitivity [80]. Thus, these data demonstrated that the ceramide/SM axis could open avenues to find new therapeutic targets for improvement of muscle insulin sensitivity.

\section{Circulating Sphingolipids}

In addition to intracellular-based actions, several recent studies have also highlighted a crucial role for circulating ceramides in the development of tissue insulin resistance and T2D. It is known that plasma ceramide levels are increased in obese patients [141]. In vitro studies showed that treatment of HepG2 liver cells with palmitate was associated with an increase of extracellular ceramide, suggesting that liver cells could rapidly secrete newly synthesized ceramide in response to hyperlipidemia [142]. In agreement, it has also been shown that treatment of myotubes with LDL-containing ceramide, which are produced by hepatocytes, promoted ceramide accumulation and insulin resistance [143]. In addition to lipoproteins, it has been recently shown that extracellular vesicles, which are cell-derived membranes shed both basally and under stress conditions, could be important regulators of secreted ceramide [144]. Treatment of hepatocytes with palmitate increased the release of extracellular vesicles enriched with ceramide. Importantly, these vesicles were able to stimulate macrophage chemotaxis [144]. Recently, the group of Scherer has shown that reduction of hepatic ceramide levels by overexpressing acid ceramidase prevented hepatic steatosis, but also improved insulin action in liver and adipose tissue upon exposure to high-fat diet [145]. Conversely, overexpression of this enzyme within adipose tissue also prevented hepatic steatosis and systemic insulin resistance [145]. Even if direct muscle insulin sensitivity has not been explored in this study, these observations suggest the possible existence of inter-organ communications mediated by circulating ceramide, critical to maintaining glucose homeostasis. Therefore, more work will be required to dissect the molecular mechanisms involved in the secretion of hepatic ceramide and the action of these circulating ceramides in the development of insulin resistance.

Quantifying circulating sphingolipid concentrations has become even more important since the demonstration that some of them could be used as biomarkers to identify individuals who are at risk to develop T2D. Indeed, searching for plasma lipid species whose concentrations correlate with various parameters of glucose homeostasis and susceptibility to T2D, we recently found that levels of ceramides and their precursor dihydroceramides were closely associated with glucose intolerance and defects in insulin secretion in mice at a pre-diabetic state [146]. Interestingly, another study revealed that higher plasma ceramide content, along with saturated FA concentrations, are prospectively associated with higher fasting insulin and insulin resistance in the Strong Heart Family Study cohort (a population at high risk of diabetes) [73]. Importantly, dihydroceramides were found to be significantly elevated in 
the plasma of individuals from the so-called (Epidemiologic Data on the Insulin Resistance Syndrome) (DESIR) cohort who will progress to diabetes up to nine years before the onset of the disease [146]. We also found recently that circulating dihydroceramides could be good T2D biomarkers, probably better than circulating ceramides [147].

Altogether, these observations suggest that lowering ceramides might be a target in pre-diabetes. Therefore, these lipids may serve as early biomarkers of, and help identify, metabolic deregulation in the pathogenesis of T2D. In line with this observation, the Mayo Clinic recently introduced a diagnostic test that quantifies plasma ceramides in order to identify patients at risk of major adverse cardiac events, suggesting that circulating ceramide could become the new cholesterol [148].

\section{Conclusion}

Over the years, studies have demonstrated that ceramides (and some of their derivate) play a crucial and deleterious role in the regulation of tissue insulin sensitivity. In muscles, there is much evidence now to say that these lipids have a major influence on the insulin response under lipotoxic conditions. The priority, however, remains to find out for sure which ceramide species mediates palmitate-induced insulin-resistance in this tissue. Up to now, it looks like C18-ceramides could be good candidates. These efforts will be crucial to identify potential targets for the development of drugs, reducing the risk of lipid-associated disorders and their metabolic and cardiovascular diseases.

To complicate the scheme, inter-organ dialogues surely exist through the secretion of sphingolipids via lipoproteins/exosomes. We are only at the beginning of understanding how and in what circumstances circulating sphingolipids could influence (positively or negatively) the insulin response of peripheral tissues such as skeletal muscles. Clearly, more work is needed to understand how the lipid networks that exist between organs function and regulate carbohydrate homeostasis.

Author Contributions: Conceived the idea: E.H. Wrote the manuscript: C.L.B., S.T.-C., O.B., H.L.S., and E.H. Figure preparation: C.L.B. Critically reviewed the manuscript and figures: C.L.B., S.T.-C., O.B., H.L.S., and E.H. All authors approved the final manuscript.

Funding: This study was supported by INSERM and the Société Francophone du Diabète.

Acknowledgments: The authors would like to thank E. Eschenbrenner (Université Paris-Saclay, France) for his great contribution in the design of the figures.

Conflicts of Interest: The authors declare no conflicts of interest.

$\begin{array}{ll}\text { Abbreviations } \\ \text { aSMase } & \text { Acid sphingomyelinase } \\ \text { C1P } & \text { Ceramide-1-phosphate } \\ \text { CerS } & \text { Ceramide synthase } \\ \text { CERT } & \text { Ceramide transporter } \\ \text { DAG } & \text { Diacylglycerols } \\ \text { DES } & \text { Dihydroceramide } \Delta 4 \text {-desaturase } \\ \text { FA } & \text { Fatty acids } \\ \text { FABP } & \text { Fatty acid binging protein } \\ \text { FAT } & \text { Fatty acid translocase } \\ \text { FATP } & \text { Fatty acid transport protein } \\ \text { G6P } & \text { Glucose-6-phosphate } \\ \text { GlcCer } & \text { Glucosylceramides } \\ \text { GLUT4 } & \text { Glucose transporter 4 } \\ \text { GM3 } & \text { Monosialodihexosylganglioside } \\ \text { GM3S } & \text { GM3 synthase } \\ \text { GS } & \text { Glycogen synthase } \\ \text { SK3 } & \text { Glycogen synthase kinase 3 } \\ \text { IR } & \text { Insulin receptor }\end{array}$




$\begin{array}{ll}\text { IRS } & \text { Insulin receptor substrate } \\ \text { JNK } & \text { c-Jun NH2-terminal kinase } \\ \text { KDHR } & \text { 3-Ketodihydrosphingosine reductase } \\ \text { nSMase } & \text { Neutral sphingomyelinase } \\ \text { PC } & \text { Phosphatidylcholine } \\ \text { PE } & \text { Phosphatidylethanolamine } \\ \text { PFK } & \text { Phospho-fructo-kinase } \\ \text { PH } & \text { Pleckstrin homology } \\ \text { PI3K } & \text { Phosphoinositide-3-kinase } \\ \text { PKR } & \text { Double stranded ARN-activated protein kinase } \\ \text { PM } & \text { Plasma membrane } \\ \text { PP2A } & \text { Protein phosphatase 2A } \\ \text { ER } & \text { Endoplasmic reticulum } \\ \text { S1P } & \text { Sphingosine-1-phosphate } \\ \text { SL } & \text { Sphingolipids } \\ \text { SM } & \text { Sphingomyelin } \\ \text { MS } & \text { Sphingomyelin synthase } \\ \text { SphK } & \text { Sphingosine kinase } \\ \text { SPT } & \text { Serine palmitoyl transferase } \\ \text { T1D } & \text { Type 1 diabetes } \\ \text { T2D } & \text { Type 2 diabetes } \\ \text { TG } & \text { Triglyceride } \\ \text { TNF } \alpha & \text { Tumor Necrosis Factor } \alpha \\ & \end{array}$

\section{References}

1. Boyle, J.P.; Thompson, T.J.; Gregg, E.W.; Barker, L.E.; Williamson, D.F. Projection of the year 2050 burden of diabetes in the US adult population: Dynamic modeling of incidence, mortality, and prediabetes prevalence. Popul. Health Metr. 2010, 8, 29. [CrossRef]

2. White, J.R., Jr. Economic considerations in treating patients with type 2 diabetes mellitus. Am. J. Health Syst. Pharm. 2002, 59 (Suppl. S9), S14-S17. [CrossRef] [PubMed]

3. Williams, E.P.; Mesidor, M.; Winters, K.; Dubbert, P.M.; Wyatt, S.B. Overweight and Obesity: Prevalence, Consequences, and Causes of a Growing Public Health Problem. Curr. Obes. Rep. 2015, 4, 363-370. [CrossRef]

4. Kwak, S.H.; Park, K.S. Recent progress in genetic and epigenetic research on type 2 diabetes. Exp. Mol. Med. 2016, 48, e220. [CrossRef]

5. DeFronzo, R.A.; Jacot, E.; Jequier, E.; Maeder, E.; Wahren, J.; Felber, J.P. The effect of insulin on the disposal of intravenous glucose. Results from indirect calorimetry and hepatic and femoral venous catheterization. Diabetes 1981, 30, 1000-1007. [CrossRef] [PubMed]

6. Consitt, L.A.; Bell, J.A.; Houmard, J.A. Intramuscular lipid metabolism, insulin action, and obesity. IUBMB. Life 2009, 61, 47-55. [CrossRef]

7. Katz, L.D.; Glickman, M.G.; Rapoport, S.; Ferrannini, E.; DeFronzo, R.A. Splanchnic and peripheral disposal of oral glucose in man. Diabetes 1983, 32, 675-679. [CrossRef] [PubMed]

8. Taylor, R.; Price, T.B.; Katz, L.D.; Shulman, R.G.; Shulman, G.I. Direct measurement of change in muscle glycogen concentration after a mixed meal in normal subjects. Am. J. Physiol. 1993, 265, E224-E229. [CrossRef] [PubMed]

9. DeFronzo, R.A.; Ferrannini, E.; Sato, Y.; Felig, P.; Wahren, J. Synergistic interaction between exercise and insulin on peripheral glucose uptake. J. Clin. Investig. 1981, 68, 1468-1474. [CrossRef]

10. White, M.F. The insulin signalling system and the IRS proteins. Diabetologia 1997, 40 (Suppl. S2), S2-S17. [CrossRef] [PubMed]

11. White, M.F. The IRS-signalling system: A network of docking proteins that mediate insulin action. Mol. Cell Biochem. 1998, 182, 3-11. [CrossRef] [PubMed]

12. Lavin, D.P.; White, M.F.; Brazil, D.P. IRS proteins and diabetic complications. Diabetologia 2016, 59, $2280-2291$. [CrossRef] [PubMed] 
13. Petersen, M.C.; Shulman, G.I. Mechanisms of Insulin Action and Insulin Resistance. Physiol. Rev. 2018, 98, 2133-2223. [CrossRef]

14. Mardilovich, K.; Pankratz, S.L.; Shaw, L.M. Expression and function of the insulin receptor substrate proteins in cancer. Cell Commun. Signal. 2009, 7, 14. [CrossRef] [PubMed]

15. Fantin, V.R.; Wang, Q.; Lienhard, G.E.; Keller, S.R. Mice lacking insulin receptor substrate 4 exhibit mild defects in growth, reproduction, and glucose homeostasis. Am. J. Physiol. Endocrinol. Metab. 2000, 278, E127-E133. [CrossRef] [PubMed]

16. Leevers, S.J.; Vanhaesebroeck, B.; Waterfield, M.D. Signalling through phosphoinositide 3-kinases: The lipids take centre stage. Curr. Opin. Cell Biol. 1999, 11, 219-225. [CrossRef]

17. Lawlor, M.A.; Alessi, D.R. PKB/Akt: A key mediator of cell proliferation, survival and insulin responses? J. Cell Sci. 2001, 114, 2903-2910.

18. Hajduch, E.; Litherland, G.J.; Hundal, H.S. Protein kinase B (PKB/Akt)—A key regulator of glucose transport? FEBS Lett. 2001, 492, 199-203. [CrossRef]

19. Huang, X.; Liu, G.; Guo, J.; Su, Z. The PI3K/AKT pathway in obesity and type 2 diabetes. Int. J. Biol. Sci. 2018, 14, 1483-1496. [CrossRef]

20. Vanhaesebroeck, B.; Alessi, D.R. The PI3K-PDK1 connection: More than just a road to PKB. Biochem. J. 2000, 346, 561-576.

21. Litherland, G.J.; Hajduch, E.; Hundal, H.S. Intracellular signalling mechanisms regulating glucose transport in insulin-sensitive tissues (review). Mol. Membr. Biol. 2001, 18, 195-204. [PubMed]

22. Coster, A.C.; Govers, R.; James, D.E. Insulin stimulates the entry of GLUT4 into the endosomal recycling pathway by a quantal mechanism. Traffic 2004, 5, 763-771. [CrossRef] [PubMed]

23. Huang, S.; Czech, M.P. The GLUT4 glucose transporter. Cell Metab. 2007, 5, 237-252. [CrossRef] [PubMed]

24. Cross, D.A.; Alessi, D.R.; Cohen, P.; Andjelkovich, M.; Hemmings, B.A. Inhibition of glycogen synthase kinase-3 by insulin mediated by protein kinase B. Nature 1995, 378, 785-789. [CrossRef] [PubMed]

25. Thorens, B. GLUT2, glucose sensing and glucose homeostasis. Diabetologia 2015, 58, 221-232. [CrossRef] [PubMed]

26. Ussher, J.R.; Koves, T.R.; Cadete, V.J.; Zhang, L.; Jaswal, J.S.; Swyrd, S.J.; Lopaschuk, D.G.; Proctor, S.D.; Keung, W.; Muoio, D.M.; et al. Inhibition of de novo ceramide synthesis reverses diet-induced insulin resistance and enhances whole-body oxygen consumption. Diabetes 2010, 59, 2453-2464. [CrossRef]

27. Bruce, C.R.; Risis, S.; Babb, J.R.; Yang, C.; Kowalski, G.M.; Selathurai, A.; Lee-Young, R.S.; Weir, J.M.; Yoshioka, K.; Takuwa, Y.; et al. Overexpression of sphingosine kinase 1 prevents ceramide accumulation and ameliorates muscle insulin resistance in high-fat diet-fed mice. Diabetes 2012, 61, 3148-3155. [CrossRef]

28. Hansen, D.; De, S.D.; Calders, P. Impact of Endurance Exercise Training in the Fasted State on Muscle Biochemistry and Metabolism in Healthy Subjects: Can These Effects be of Particular Clinical Benefit to Type 2 Diabetes Mellitus and Insulin-Resistant Patients? Sports Med. 2017, 47, 415-428. [CrossRef]

29. Yang, J. Enhanced skeletal muscle for effective glucose homeostasis. Prog. Mol. Biol. Transl. Sci. 2014, 121, 133-163.

30. Belfort, R.; Mandarino, L.; Kashyap, S.; Wirfel, K.; Pratipanawatr, T.; Berria, R.; DeFronzo, R.A.; Cusi, K. Dose-response effect of elevated plasma free fatty acid on insulin signaling. Diabetes 2005, 54, 1640-1648. [CrossRef]

31. Nicholson, T.; Church, C.; Baker, D.J.; Jones, S.W. The role of adipokines in skeletal muscle inflammation and insulin sensitivity. J. Inflamm. 2018, 15, 9. [CrossRef] [PubMed]

32. Metcalfe, L.K.; Smith, G.C.; Turner, N. Defining lipid mediators of insulin resistance-Controversies and challenges. J. Mol. Endocrinol. 2018, 2018. 62, R65-R82. [CrossRef]

33. Summers, S.A. Ceramides in insulin resistance and lipotoxicity. Prog. Lipid Res. 2006, 45, 42-72. [CrossRef] [PubMed]

34. Hage Hassan, R.; Bourron, O.; Hajduch, E. Defect of insulin signal in peripheral tissues: Important role of ceramide. World J. Diabetes 2014, 5, 244-257. [CrossRef] [PubMed]

35. Goodpaster, B.H.; Theriault, R.; Watkins, S.C.; Kelley, D.E. Intramuscular lipid content is increased in obesity and decreased by weight loss. Metabolism 2000, 49, 467-472. [CrossRef]

36. Malenfant, P.; Joanisse, D.R.; Theriault, R.; Goodpaster, B.H.; Kelley, D.E.; Simoneau, J.A. Fat content in individual muscle fibers of lean and obese subjects. Int. J. Obes. Relat. Metab. Disord. 2001, 25, 1316-1321. [CrossRef] [PubMed] 
37. Roepstorff, C.; Helge, J.W.; Vistisen, B.; Kiens, B. Studies of plasma membrane fatty acid-binding protein and other lipid-binding proteins in human skeletal muscle. Proc. Nutr. Soc. 2004, 63, 239-244. [CrossRef]

38. Bonen, A.; Parolin, M.L.; Steinberg, G.R.; Calles-Escandon, J.; Tandon, N.N.; Glatz, J.F.; Luiken, J.J.; Heigenhauser, G.J.; Dyck, D.J. Triacylglycerol accumulation in human obesity and type 2 diabetes is associated with increased rates of skeletal muscle fatty acid transport and increased sarcolemmal FAT/CD36. FASEB J. 2004, 18, 1144-1146. [CrossRef]

39. Watt, M.J.; Hoy, A.J. Lipid metabolism in skeletal muscle: Generation of adaptive and maladaptive intracellular signals for cellular function. Am. J. Physiol. Endocrinol. Metab 2012, 302, E1315-E1328. [CrossRef]

40. Martins, A.R.; Nachbar, R.T.; Gorjao, R.; Vinolo, M.A.; Festuccia, W.T.; Lambertucci, R.H.; Cury-Boaventura, M.F.; Silveira, L.R.; Curi, R.; Hirabara, S.M. Mechanisms underlying skeletal muscle insulin resistance induced by fatty acids: Importance of the mitochondrial function. Lipids Health Dis. 2012, 11, 30. [CrossRef]

41. Rains, J.L.; Jain, S.K. Oxidative stress, insulin signaling, and diabetes. Free Radic. Biol. Med. 2011, 50, 567-575. [CrossRef] [PubMed]

42. Kelley, D.E.; He, J.; Menshikova, E.V.; Ritov, V.B. Dysfunction of mitochondria in human skeletal muscle in type 2 diabetes. Diabetes 2002, 51, 2944-2950. [CrossRef] [PubMed]

43. Hulver, M.W.; Berggren, J.R.; Cortright, R.N.; Dudek, R.W.; Thompson, R.P.; Pories, W.J.; Macdonald, K.G.; Cline, G.W.; Shulman, G.I.; Dohm, G.L.; et al. Skeletal muscle lipid metabolism with obesity. Am. J. Physiol. Endocrinol. Metab. 2003, 284, E741-E747. [CrossRef] [PubMed]

44. Lambert, J.E.; Parks, E.J. Postprandial metabolism of meal triglyceride in humans. Biochim. Biophys. Acta 2012, 1821, 721-726. [CrossRef] [PubMed]

45. Randle, P.J.; Garland, P.B.; Hales, C.N.; Newsholme, E.A. The glucose fatty-acid cycle. Its role in insulin sensitivity and the metabolic disturbances of diabetes mellitus. Lancet 1963, 1, 785-789. [CrossRef]

46. Roden, M.; Price, T.B.; Perseghin, G.; Petersen, K.F.; Rothman, D.L.; Cline, G.W.; Shulman, G.I. Mechanism of free fatty acid-induced insulin resistance in humans. J. Clin. Investig. 1996, 97, 2859-2865. [CrossRef]

47. Anastasiou, C.A.; Kavouras, S.A.; Lentzas, Y.; Gova, A.; Sidossis, L.S.; Melidonis, A. Diabetes mellitus is associated with increased intramyocellular triglyceride, but not diglyceride, content in obese humans. Metabolism 2009, 58, 1636-1642. [CrossRef]

48. Amati, F.; Dube, J.J.; Carnero, E.A.; Edreira, M.M.; Chomentowski, P.; Coen, P.M.; Switzer, G.E.; Bickel, P.E.; Stefanovic-Racic, M.; Toledo, F.G.; et al. Skeletal-Muscle Triglycerides, Diacylglycerols, and Ceramides in Insulin Resistance: Another Paradox in Endurance-Trained Athletes? Diabetes 2011, 60, 2588-2597. [CrossRef]

49. Petersen, M.C.; Shulman, G.I. Roles of Diacylglycerols and Ceramides in Hepatic Insulin Resistance. Trends Pharmacol. Sci. 2017, 38, 649-665. [CrossRef]

50. Liu, L.; Yu, S.; Khan, R.S.; Ables, G.P.; Bharadwaj, K.G.; Hu, Y.; Huggins, L.A.; Eriksson, J.W.; Buckett, L.K.; Turnbull, A.V.; et al. DGAT1 deficiency decreases PPAR expression and does not lead to lipotoxicity in cardiac and skeletal muscle. J. Lipid Res. 2011, 52, 732-744. [CrossRef]

51. Chibalin, A.V.; Leng, Y.; Vieira, E.; Krook, A.; Bjornholm, M.; Long, Y.C.; Kotova, O.; Zhong, Z.; Sakane, F.; Steiler, T.; et al. Downregulation of diacylglycerol kinase delta contributes to hyperglycemia-induced insulin resistance. Cell 2008, 132, 375-386. [CrossRef] [PubMed]

52. Brose, N.; Betz, A.; Wegmeyer, H. Divergent and convergent signaling by the diacylglycerol second messenger pathway in mammals. Curr. Opin. Neurobiol. 2004, 14, 328-340. [CrossRef] [PubMed]

53. Erion, D.M.; Shulman, G.I. Diacylglycerol-mediated insulin resistance. Nat. Med. 2010, 16, 400-402. [CrossRef] [PubMed]

54. Turinsky, J.; O'Sullivan, D.M.; Bayly, B.P. 1,2-Diacylglycerol and ceramide levels in insulin-resistant tissues of the rat in vivo. J. Biol. Chem. 1990, 265, 16880-16885. [PubMed]

55. Hannun, Y.A.; Obeid, L.M. Principles of bioactive lipid signalling: Lessons from sphingolipids. Nat. Rev. Mol. Cell Biol. 2008, 9, 139-150. [CrossRef] [PubMed]

56. Castro, B.M.; Prieto, M.; Silva, L.C. Ceramide: A simple sphingolipid with unique biophysical properties. Prog. Lipid Res. 2014, 54, 53-67. [CrossRef] [PubMed]

57. Allen, J.A.; Halverson-Tamboli, R.A.; Rasenick, M.M. Lipid raft microdomains and neurotransmitter signalling. Nat. Rev. Neurosci. 2007, 8, 128-140. [CrossRef]

58. Mullen, T.D.; Hannun, Y.A.; Obeid, L.M. Ceramide synthases at the centre of sphingolipid metabolism and biology. Biochem. J. 2012, 441, 789-802. [CrossRef] 
59. Colombini, M. Ceramide channels and their role in mitochondria-mediated apoptosis. Biochim. Biophys. Acta 2010, 1797, 1239-1244. [CrossRef]

60. Spiegel, S.; Merrill, A.H., Jr. Sphingolipid metabolism and cell growth regulation. FASEB J. 1996, 10, 1388-1397. [CrossRef]

61. Saddoughi, S.A.; Ogretmen, B. Diverse functions of ceramide in cancer cell death and proliferation. Adv. Cancer Res. 2013, 117, 37-58. [PubMed]

62. Perry, D.K.; Hannun, Y.A. The role of ceramide in cell signaling. Biochim. Biophys. Acta 1998, 1436, $233-243$. [CrossRef]

63. Uchida, Y. Ceramide signaling in mammalian epidermis. Biochim. Biophys. Acta 2014, 1841, $453-462$. [CrossRef] [PubMed]

64. Zheng, W.; Kollmeyer, J.; Symolon, H.; Momin, A.; Munter, E.; Wang, E.; Kelly, S.; Allegood, J.C.; Liu, Y.; Peng, Q.; et al. Ceramides and other bioactive sphingolipid backbones in health and disease: Lipidomic analysis, metabolism and roles in membrane structure, dynamics, signaling and autophagy. Biochim. Biophys. Acta 2006, 1758, 1864-1884. [CrossRef] [PubMed]

65. Gault, C.R.; Obeid, L.M.; Hannun, Y.A. An overview of sphingolipid metabolism: From synthesis to breakdown. Adv. Exp. Med. Biol. 2010, 688, 1-23. [PubMed]

66. Kitatani, K.; Idkowiak-Baldys, J.; Hannun, Y.A. The sphingolipid salvage pathway in ceramide metabolism and signaling. Cell Signal. 2008, 20, 1010-1018. [CrossRef] [PubMed]

67. Schmitz-Peiffer, C.; Craig, D.L.; Biden, T.J. Ceramide generation is sufficient to account for the inhibition of the insulin-stimulated PKB pathway in C2C12 skeletal muscle cells pretreated with palmitate. J. Biol. Chem. 1999, 274, 24202-24210. [CrossRef]

68. Hajduch, E.; Alessi, D.R.; Hemmings, B.A.; Hundal, H.S. Constitutive activation of protein kinase B alpha by membrane targeting promotes glucose and system a amino acid transport, protein synthesis, and inactivation of glycogen synthase kinase 3 in L6 muscle cells. Diabetes 1998, 47, 1006-1013. [CrossRef]

69. Hajduch, E.; Balendran, A.; Batty, I.H.; Litherland, G.J.; Blair, A.S.; Downes, C.P.; Hundal, H.S. Ceramide impairs the insulin-dependent membrane recruitment of protein kinase B leading to a loss in downstream signalling in L6 skeletal muscle cells. Diabetologia 2001, 44, 173-183. [CrossRef]

70. Watson, M.L.; Coghlan, M.; Hundal, H.S. Modulating serine palmitoyl transferase (SPT) expression and activity unveils a crucial role in lipid-induced insulin resistance in rat skeletal muscle cells. Biochem. J. 2009, 417, 791-801. [CrossRef]

71. Cazzolli, R.; Carpenter, L.; Biden, T.J.; Schmitz-Peiffer, C. A role for protein phosphatase 2A-like activity, but not atypical protein kinase Czeta, in the inhibition of protein kinase B/Akt and glycogen synthesis by palmitate. Diabetes 2001, 50, 2210-2218. [CrossRef] [PubMed]

72. Bourbon, N.A.; Sandirasegarane, L.; Kester, M. Ceramide-induced inhibition of Akt is mediated through protein kinase Czeta: Implications for growth arrest. J. Biol. Chem. 2002, 277, 3286-3292. [CrossRef] [PubMed]

73. Chavez, J.A.; Summers, S.A. Characterizing the effects of saturated fatty acids on insulin signaling and ceramide and diacylglycerol accumulation in 3T3-L1 adipocytes and C2C12 myotubes. Arch. Biochem. Biophys. 2003, 419, 101-109. [CrossRef] [PubMed]

74. Powell, D.J.; Hajduch, E.; Kular, G.; Hundal, H.S. Ceramide Disables 3-Phosphoinositide Binding to the Pleckstrin Homology Domain of Protein Kinase B (PKB)/Akt by a PKCzeta-Dependent Mechanism. Mol. Cell Biol. 2003, 23, 7794-7808. [CrossRef] [PubMed]

75. Powell, D.J.; Turban, S.; Gray, A.; Hajduch, E.; Hundal, H.S. Intracellular ceramide synthesis and protein kinase Czeta activation play an essential role in palmitate-induced insulin resistance in rat L6 skeletal muscle cells. Biochem. J. 2004, 382, 619-629. [CrossRef] [PubMed]

76. Hajduch, E.; Turban, S.; Le Liepvre, X.; Le Lay, S.; Lipina, C.; Dimopoulos, N.; Dugail, I.; Hundal, H.S. Targeting of PKCzeta and PKB to caveolin-enriched microdomains represents a crucial step underpinning the disruption in PKB-directed signalling by ceramide. Biochem. J. 2008, 410, 369-379. [CrossRef] [PubMed]

77. Frangioudakis, G.; Diakanastasis, B.; Liao, B.Q.; Saville, J.T.; Hoffman, N.J.; Mitchell, T.W.; Schmitz-Peiffer, C. Ceramide accumulation in L6 skeletal muscle cells due to increased activity of ceramide synthase isoforms has opposing effects on insulin action to those caused by palmitate treatment. Diabetologia 2013, 56, 2697-2701. [CrossRef] 
78. Mahfouz, R.; Khoury, R.; Blachnio-Zabielska, A.; Turban, S.; Loiseau, N.; Lipina, C.; Stretton, C.; Bourron, O.; Ferre, P.; Foufelle, F.; et al. Characterising the Inhibitory Actions of Ceramide upon Insulin Signaling in Different Skeletal Muscle Cell Models: A Mechanistic Insight. PLoS. ONE 2014, 9, e101865. [CrossRef]

79. Hage Hassan, R.; Pacheco de Sousa, A.C.; Mahfouz, R.; Hainault, I.; Blachnio-Zabielska, A.; Bourron, O.; Koskas, F.; Gorski, J.; Ferre, P.; Foufelle, F.; et al. Sustained Action of Ceramide on the Insulin Signaling Pathway in Muscle Cells: Implication of the double-stranded RNA-activated protein kinase. J. Biol. Chem. 2016, 291, 3019-3029. [CrossRef]

80. Bandet, C.L.; Mahfouz, R.; Veret, J.; Sotiropoulos, A.; Poirier, M.; Giussani, P.; Campana, M.; Philippe, E.; Blachnio-Zabielska, A.; Ballaire, R.; et al. Ceramide Transporter CERT Is Involved in Muscle Insulin Signaling Defects Under Lipotoxic Conditions. Diabetes 2018, 67, 1258-1271. [CrossRef]

81. Pillon, N.J.; Frendo-Cumbo, S.; Jacobson, M.R.; Liu, Z.; Milligan, P.L.; Hoang, B.H.; Zierath, J.R.; Bilan, P.J.; Brozinick, J.T.; Klip, A. Sphingolipid changes do not underlie fatty acid-evoked GLUT4 insulin resistance nor inflammation signals in muscle cells. J. Lipid Res. 2018, 59, 1148-1163. [CrossRef] [PubMed]

82. Huang, S.; Huang, S.; Wang, X.; Zhang, Q.; Liu, J.; Leng, Y. Downregulation of lipin-1 induces insulin resistance by increasing intracellular ceramide accumulation in C2C12 myotubes. Int. J. Biol. Sci. 2017, 13, 1-12. [CrossRef] [PubMed]

83. Holland, W.L.; Brozinick, J.T.; Wang, L.P.; Hawkins, E.D.; Sargent, K.M.; Liu, Y.; Narra, K.; Hoehn, K.L.; Knotts, T.A.; Siesky, A.; et al. Inhibition of ceramide synthesis ameliorates glucocorticoid-, saturated-fat-, and obesity-induced insulin resistance. Cell Metab. 2007, 5, 167-179. [CrossRef] [PubMed]

84. Turner, N.; Kowalski, G.M.; Leslie, S.J.; Risis, S.; Yang, C.; Lee-Young, R.S.; Babb, J.R.; Meikle, P.J.; Lancaster, G.I.; Henstridge, D.C.; et al. Distinct patterns of tissue-specific lipid accumulation during the induction of insulin resistance in mice by high-fat feeding. Diabetologia 2013, 56, 1638-1648. [CrossRef] [PubMed]

85. Blachnio-Zabielska, A.U.; Chacinska, M.; Vendelbo, M.H.; Zabielski, P. The Crucial Role of C18-Cer in Fat-Induced Skeletal Muscle Insulin Resistance. Cell Physiol. Biochem. 2016, 40, 1207-1220. [CrossRef] [PubMed]

86. Turner, N.; Lim, X.Y.; Toop, H.D.; Osborne, B.; Brandon, A.E.; Taylor, E.N.; Fiveash, C.E.; Govindaraju, H.; Teo, J.D.; McEwen, H.P.; et al. A selective inhibitor of ceramide synthase 1 reveals a novel role in fat metabolism. Nat. Commun. 2018, 9, 3165. [CrossRef] [PubMed]

87. Turpin-Nolan, S.M.; Hammerschmidt, P.; Chen, W.; Jais, A.; Timper, K.; Awazawa, M.; Brodesser, S.; Bruning, J.C. CerS1-Derived C18:0 Ceramide in Skeletal Muscle Promotes Obesity-Induced Insulin Resistance. Cell Rep. 2019, 26, 1-10. [CrossRef]

88. Adams, J.M.; Pratipanawatr, T.; Berria, R.; Wang, E.; DeFronzo, R.A.; Sullards, M.C.; Mandarino, L.J. Ceramide content is increased in skeletal muscle from obese insulin-resistant humans. Diabetes 2004, 53, 25-31. [CrossRef]

89. Straczkowski, M.; Kowalska, I.; Baranowski, M.; Nikolajuk, A.; Otziomek, E.; Zabielski, P.; Adamska, A.; Blachnio, A.; Gorski, J.; Gorska, M. Increased skeletal muscle ceramide level in men at risk of developing type 2 diabetes. Diabetologia 2007, 50, 2366-2373. [CrossRef]

90. Coen, P.M.; Dube, J.J.; Amati, F.; Stefanovic-Racic, M.; Ferrell, R.E.; Toledo, F.G.; Goodpaster, B.H. Insulin resistance is associated with higher intramyocellular triglycerides in type I but not type II myocytes concomitant with higher ceramide content. Diabetes 2010, 59, 80-88. [CrossRef]

91. Coen, P.M.; Hames, K.C.; Leachman, E.M.; Delany, J.P.; Ritov, V.B.; Menshikova, E.V.; Dube, J.J.; Stefanovic-Racic, M.; Toledo, F.G.; Goodpaster, B.H. Reduced skeletal muscle oxidative capacity and elevated ceramide but not diacylglycerol content in severe obesity. Obesity 2013, 21, 2362-2371. [CrossRef] [PubMed]

92. Bergman, B.C.; Brozinick, J.T.; Strauss, A.; Bacon, S.; Kerege, A.; Bui, H.H.; Sanders, P.; Siddall, P.; Wei, T.; Thomas, M.K.; et al. Muscle sphingolipids during rest and exercise: A C18:0 signature for insulin resistance in humans. Diabetologia 2016, 59, 785-798. [CrossRef] [PubMed]

93. Broskey, N.T.; Obanda, D.N.; Burton, J.H.; Cefalu, W.T.; Ravussin, E. Skeletal muscle ceramides and daily fat oxidation in obesity and diabetes. Metabolism 2018, 82, 118-123. [CrossRef] [PubMed]

94. Perreault, L.; Newsom, S.A.; Strauss, A.; Kerege, A.; Kahn, D.E.; Harrison, K.A.; Snell-Bergeon, J.K.; Nemkov, T.; D'Alessandro, A.; Jackman, M.R.; et al. Intracellular localization of diacylglycerols and sphingolipids influences insulin sensitivity and mitochondrial function in human skeletal muscle. JCI. Insight. 2018, 3. [CrossRef] [PubMed] 
95. Lemaitre, R.N.; Yu, C.; Hoofnagle, A.; Hari, N.; Jensen, P.N.; Fretts, A.M.; Umans, J.G.; Howard, B.V.; Sitlani, C.M.; Siscovick, D.S.; et al. Circulating Sphingolipids, Insulin, HOMA-IR, and HOMA-B: The Strong Heart Family Study. Diabetes 2018, 67, 1663-1672. [CrossRef]

96. Stratford, S.; Hoehn, K.L.; Liu, F.; Summers, S.A. Regulation of insulin action by ceramide: Dual mechanisms linking ceramide accumulation to the inhibition of Akt/protein kinase B. J. Biol. Chem. 2004, 279, 36608-36615. [CrossRef] [PubMed]

97. Turban, S.; Hajduch, E. Protein kinase C isoforms: Mediators of reactive lipid metabolites in the development of insulin resistance. FEBS Lett. 2011, 585, 269-274. [CrossRef]

98. Doornbos, R.P.; Theelen, M.; van der Hoeven, P.C.; van Blitterswijk, W.J.; Verkleij, A.J.; en Henegouwen, P.M.V.B. Protein kinase Czeta is a negative regulator of protein kinase B activity. J. Biol. Chem. 1999, 274, 8589-8596. [CrossRef]

99. Konishi, H.; Kuroda, S.; Kikkawa, U. The pleckstrin homology domain of RAC protein kinase associates with the regulatory domain of protein kinase C zeta. Biochem. Biophys. Res. Commun. 1994, 205, 1770-1775. [CrossRef]

100. Mao, M.; Fang, X.; Lu, Y.; Lapushin, R.; Bast, R.C., Jr.; Mills, G.B. Inhibition of growth-factor-induced phosphorylation and activation of protein kinase B/Akt by atypical protein kinase $\mathrm{C}$ in breast cancer cells. Biochem. J. 2000, 352 Pt 2, 475-482. [CrossRef]

101. Razani, B.; Woodman, S.E.; Lisanti, M.P. Caveolae: From cell biology to animal physiology. Pharmacol. Rev. 2002, 54, 431-467. [CrossRef] [PubMed]

102. Le Lay, S.; Hajduch, E.; Lindsay, M.R.; Le Liepvre, X.; Thiele, C.; Ferre, P.; Parton, R.G.; Kurzchalia, T.; Simons, K.; Dugail, I. Cholesterol-induced caveolin targeting to lipid droplets in adipocytes: A role for caveolar endocytosis. Traffic 2006, 7, 549-561. [CrossRef] [PubMed]

103. Oka, N.; Yamamoto, M.; Schwencke, C.; Kawabe, J.; Ebina, T.; Ohno, S.; Couet, J.; Lisanti, M.P.; Ishikawa, Y. Caveolin interaction with protein kinase $C$. Isoenzyme-dependent regulation of kinase activity by the caveolin scaffolding domain peptide. J. Biol. Chem. 1997, 272, 33416-33421. [CrossRef] [PubMed]

104. Blouin, C.M.; Prado, C.; Takane, K.K.; Lasnier, F.; Garcia-Ocana, A.; Ferre, P.; Dugail, I.; Hajduch, E. Plasma membrane subdomain compartmentalization contributes to distinct mechanisms of ceramide action on insulin signaling. Diabetes 2010, 59, 600-610. [CrossRef] [PubMed]

105. Silveira, L.R.; Fiamoncini, J.; Hirabara, S.M.; Procopio, J.; Cambiaghi, T.D.; Pinheiro, C.H.; Lopes, L.R.; Curi, R. Updating the effects of fatty acids on skeletal muscle. J. Cell Physiol. 2008, 217, 1-12. [CrossRef] [PubMed]

106. Petersen, K.F.; Shulman, G.I. Etiology of insulin resistance. Am. J. Med. 2006, 119, S10-S16. [CrossRef] [PubMed]

107. Tanti, J.F.; Gual, P.; Gremeaux, T.; Gonzalez, T.; Barres, R.; Le Marchand-Brustel, Y. Alteration in insulin action: Role of IRS-1 serine phosphorylation in the retroregulation of insulin signalling. Ann. Endocrinol. 2004, 65, 43-48. [CrossRef]

108. Carvalho, B.M.; Oliveira, A.G.; Ueno, M.; Araujo, T.G.; Guadagnini, D.; Carvalho-Filho, M.A.; Geloneze, B.; Lima, M.M.; Pareja, J.C.; Carvalheira, J.B.; et al. Modulation of Double-Stranded RNA-Activated Protein Kinase in Insulin Sensitive Tissues of Obese Humans. Obesity 2013, 21, 2452-2457. [CrossRef]

109. Carvalho-Filho, M.A.; Carvalho, B.M.; Oliveira, A.G.; Guadagnini, D.; Ueno, M.; Dias, M.M.; Tsukumo, D.M.; Hirabara, S.M.; Reis, L.F.; Curi, R.; et al. Double-Stranded RNA-Activated Protein Kinase Is a Key Modulator of Insulin Sensitivity in Physiological Conditions and in Obesity in Mice. Endocrinology 2012, 153, 5261-5274. [CrossRef]

110. Nakamura, T.; Arduini, A.; Baccaro, B.; Furuhashi, M.; Hotamisligil, G.S. Small molecule inhibitors of PKR improve glucose homeostasis in obese, diabetic mice. Diabetes 2013, 63, 526-534. [CrossRef]

111. Cimmino, I.; Lorenzo, V.; Fiory, F.; Doti, N.; Ricci, S.; Cabaro, S.; Liotti, A.; Vitagliano, L.; Longo, M.; Miele, C.; et al. A peptide antagonist of Prep1-p160 interaction improves ceramide-induced insulin resistance in skeletal muscle cells. Oncotarget 2017, 8, 71845-71858. [CrossRef] [PubMed]

112. Oriente, F.; Fernandez Diaz, L.C.; Miele, C.; Iovino, S.; Mori, S.; Diaz, V.M.; Troncone, G.; Cassese, A.; Formisano, P.; Blasi, F.; et al. Prep1 deficiency induces protection from diabetes and increased insulin sensitivity through a p160-mediated mechanism. Mol. Cell Biol. 2008, 28, 5634-5645. [CrossRef] [PubMed] 
113. Oriente, F.; Cabaro, S.; Liotti, A.; Longo, M.; Parrillo, L.; Pagano, T.B.; Raciti, G.A.; Penkov, D.; Paciello, O.; Miele, C.; et al. PREP1 deficiency downregulates hepatic lipogenesis and attenuates steatohepatitis in mice. Diabetologia 2013, 56, 2713-2722. [CrossRef] [PubMed]

114. Turpin, S.M.; Nicholls, H.T.; Willmes, D.M.; Mourier, A.; Brodesser, S.; Wunderlich, C.M.; Mauer, J.; Xu, E.; Hammerschmidt, P.; Bronneke, H.S.; et al. Obesity-Induced CerS6-Dependent C16:0 Ceramide Production Promotes Weight Gain and Glucose Intolerance. Cell Metab. 2014, 20, 678-686. [CrossRef] [PubMed]

115. Raichur, S.; Wang, S.T.; Chan, P.W.; Li, Y.; Ching, J.; Chaurasia, B.; Dogra, S.; Ohman, M.K.; Takeda, K.; Sugii, S.; et al. CerS2 Haploinsufficiency Inhibits beta-oxidation and Confers Susceptibility to Diet-Induced Steatohepatitis and Insulin Resistance. Cell Metab. 2014, 20, 687-695. [CrossRef] [PubMed]

116. Hla, T.; Kolesnick, R. C16:0-ceramide signals insulin resistance. Cell Metab. 2014, 20, 703-705. [CrossRef] [PubMed]

117. Teruel, T.; Hernandez, R.; Lorenzo, M. Ceramide mediates insulin resistance by tumor necrosis factor-alpha in brown adipocytes by maintaining Akt in an inactive dephosphorylated state. Diabetes 2001, 50, 2563-2571. [CrossRef]

118. Selathurai, A.; Kowalski, G.M.; Burch, M.L.; Sepulveda, P.; Risis, S.; Lee-Young, R.S.; Lamon, S.; Meikle, P.J.; Genders, A.J.; McGee, S.L.; et al. The CDP-Ethanolamine Pathway Regulates Skeletal Muscle Diacylglycerol Content and Mitochondrial Biogenesis without Altering Insulin Sensitivity. Cell Metab. 2015, 21, 718-730. [CrossRef]

119. Timmers, S.; de Vogel-van den Bosch, J.; Hesselink, M.K.; van Beurden, D.; Schaart, G.; Ferraz, M.J.; Losen, M.; Martinez-Martinez, P.; de Baets, M.H.; Aerts, J.M.; et al. Paradoxical increase in TAG and DAG content parallel the insulin sensitizing effect of unilateral DGAT1 overexpression in rat skeletal muscle. PLoS ONE 2011, 6, e14503. [CrossRef]

120. Timmers, S.; Nabben, M.; Bosma, M.; van Bree, B.; Lenaers, E.; van Beurden, D.; Schaart, G.; Westerterp-Plantenga, M.S.; Langhans, W.; Hesselink, M.K.; et al. Augmenting muscle diacylglycerol and triacylglycerol content by blocking fatty acid oxidation does not impede insulin sensitivity. Proc. Natl. Acad. Sci. USA 2012, 109, 11711-11716. [CrossRef]

121. Perreault, L.; Bergman, B.C.; Hunerdosse, D.M.; Eckel, R.H. Altered intramuscular lipid metabolism relates to diminished insulin action in men, but not women, in progression to diabetes. Obesity 2010, 18, 2093-2100. [CrossRef] [PubMed]

122. Jocken, J.W.; Moro, C.; Goossens, G.H.; Hansen, D.; Mairal, A.; Hesselink, M.K.; Langin, D.; van Loon, L.J.; Blaak, E.E. Skeletal muscle lipase content and activity in obesity and type 2 diabetes. J. Clin. Endocrinol. Metab. 2010, 95, 5449-5453. [CrossRef] [PubMed]

123. Yu, C.; Chen, Y.; Cline, G.W.; Zhang, D.; Zong, H.; Wang, Y.; Bergeron, R.; Kim, J.K.; Cushman, S.W.; Cooney, G.J.; et al. Mechanism by which fatty acids inhibit insulin activation of insulin receptor substrate-1 (IRS-1)-associated phosphatidylinositol 3-kinase activity in muscle. J. Biol. Chem. 2002, 277, 50230-50236. [CrossRef] [PubMed]

124. Itani, S.I.; Ruderman, N.B.; Schmieder, F.; Boden, G. Lipid-induced insulin resistance in human muscle is associated with changes in diacylglycerol, protein kinase C, and IkappaB-alpha. Diabetes 2002, 51, 2005-2011. [CrossRef] [PubMed]

125. Vistisen, B.; Hellgren, L.I.; Vadset, T.; Scheede-Bergdahl, C.; Helge, J.W.; Dela, F.; Stallknecht, B. Effect of gender on lipid-induced insulin resistance in obese subjects. Eur. J. Endocrinol. 2008, 158, 61-68. [CrossRef] [PubMed]

126. Yuzefovych, L.; Wilson, G.; Rachek, L. Different effects of oleate vs. palmitate on mitochondrial function, apoptosis, and insulin signaling in L6 skeletal muscle cells: Role of oxidative stress. Am. J. Physiol. Endocrinol. Metab. 2010, 299, E1096-E1105. [CrossRef] [PubMed]

127. Mitsutake, S.; Date, T.; Yokota, H.; Sugiura, M.; Kohama, T.; Igarashi, Y. Ceramide kinase deficiency improves diet-induced obesity and insulin resistance. FEBS Lett. 2012, 586, 1300-1305. [CrossRef] [PubMed]

128. Maceyka, M.; Harikumar, K.B.; Milstien, S.; Spiegel, S. Sphingosine-1-phosphate signaling and its role in disease. Trends Cell Biol. 2012, 22, 50-60. [CrossRef]

129. Fayyaz, S.; Japtok, L.; Kleuser, B. Divergent role of sphingosine 1-phosphate on insulin resistance. Cell Physiol. Biochem. 2014, 34, 134-147. [CrossRef]

130. Hanada, K. Intracellular trafficking of ceramide by ceramide transfer protein. Proc. Jpn. Acad. Ser. B Phys. Biol. Sci. 2010, 86, 426-437. [CrossRef] 
131. Giussani, P.; Brioschi, L.; Bassi, R.; Riboni, L.; Viani, P. Phosphatidylinositol 3-kinase/AKT pathway regulates the endoplasmic reticulum to golgi traffic of ceramide in glioma cells: A link between lipid signaling pathways involved in the control of cell survival. J. Biol. Chem. 2009, 284, 5088-5096. [CrossRef] [PubMed]

132. Alpy, F.; Tomasetto, C. Give lipids a START: The StAR-related lipid transfer (START) domain in mammals. J. Cell Sci. 2005, 118, 2791-2801. [CrossRef]

133. Langeveld, M.; Aerts, J.M. Glycosphingolipids and insulin resistance. Prog. Lipid Res. 2009, 48, $196-205$. [CrossRef] [PubMed]

134. Yamashita, T.; Hashiramoto, A.; Haluzik, M.; Mizukami, H.; Beck, S.; Norton, A.; Kono, M.; Tsuji, S.; Daniotti, J.L.; Werth, N.; et al. Enhanced insulin sensitivity in mice lacking ganglioside GM3. Proc. Natl. Acad. Sci. USA 2003, 100, 3445-3449. [CrossRef]

135. Chavez, J.A.; Siddique, M.M.; Wang, S.T.; Ching, J.; Shayman, J.A.; Summers, S.A. Ceramides and glucosylceramides are independent antagonists of insulin signaling. J. Biol. Chem. 2014, 289, 723-734. [CrossRef] [PubMed]

136. Zhao, H.; Przybylska, M.; Wu, I.H.; Zhang, J.; Siegel, C.; Komarnitsky, S.; Yew, N.S.; Cheng, S.H. Inhibiting glycosphingolipid synthesis improves glycemic control and insulin sensitivity in animal models of type 2 diabetes. Diabetes 2007, 56, 1210-1218. [CrossRef] [PubMed]

137. Sekimoto, J.; Kabayama, K.; Gohara, K.; Inokuchi, J. Dissociation of the insulin receptor from caveolae during TNFalpha-induced insulin resistance and its recovery by D-PDMP. FEBS Lett. 2012, 586, 191-195. [CrossRef]

138. Kabayama, K.; Sato, T.; Saito, K.; Loberto, N.; Prinetti, A.; Sonnino, S.; Kinjo, M.; Igarashi, Y.; Inokuchi, J. Dissociation of the insulin receptor and caveolin-1 complex by ganglioside GM3 in the state of insulin resistance. Proc. Natl. Acad. Sci. USA 2007, 104, 13678-13683. [CrossRef]

139. Floegel, A.; Stefan, N.; Yu, Z.; Muhlenbruch, K.; Drogan, D.; Joost, H.G.; Fritsche, A.; Haring, H.U.; de Angelis, M.H.; Peters, A.; et al. Identification of serum metabolites associated with risk of type 2 diabetes using a targeted metabolomic approach. Diabetes 2013, 62, 639-648. [CrossRef]

140. Park, M.; Kaddai, V.; Ching, J.; Fridianto, K.T.; Sieli, R.J.; Sugii, S.; Summers, S.A. A Role for Ceramides, but NOT Sphingomyelins, as antagonists of insulin signaling and mitochondrial metabolism in C2C12 myotubes. J. Biol. Chem. 2016, 291, 23978-23988. [CrossRef]

141. Haus, J.M.; Kashyap, S.R.; Kasumov, T.; Zhang, R.; Kelly, K.R.; DeFronzo, R.A.; Kirwan, J.P. Plasma ceramides are elevated in obese subjects with type 2 diabetes and correlate with the severity of insulin resistance. Diabetes 2009, 58, 337-343. [CrossRef] [PubMed]

142. Watt, M.J.; Barnett, A.C.; Bruce, C.R.; Schenk, S.; Horowitz, J.F.; Hoy, A.J. Regulation of plasma ceramide levels with fatty acid oversupply: Evidence that the liver detects and secretes de novo synthesised ceramide. Diabetologia 2012, 55, 2741-2746. [CrossRef] [PubMed]

143. Boon, J.; Hoy, A.J.; Stark, R.; Brown, R.D.; Meex, R.C.; Henstridge, D.C.; Schenk, S.; Meikle, P.J.; Horowitz, J.F.; Kingwell, B.A.; et al. Ceramides contained in LDL are elevated in type 2 diabetes and promote inflammation and skeletal muscle insulin resistance. Diabetes 2013, 62, 401-410. [CrossRef] [PubMed]

144. Kakazu, E.; Mauer, A.S.; Yin, M.; Malhi, H. Hepatocytes release ceramide-enriched pro-inflammatory extracellular vesicles in an IRE1alpha-dependent manner. J. Lipid Res. 2016, 57, 233-245. [CrossRef] [PubMed]

145. Xia, J.Y.; Holland, W.L.; Kusminski, C.M.; Sun, K.; Sharma, A.X.; Pearson, M.J.; Sifuentes, A.J.; McDonald, J.G.; Gordillo, R.; Scherer, P.E. Targeted Induction of Ceramide Degradation Leads to Improved Systemic Metabolism and Reduced Hepatic Steatosis. Cell Metab. 2015, 22, 266-278. [CrossRef] [PubMed]

146. Wigger, L.; Cruciani-Guglielmacci, C.; Nicolas, A.; Denom, J.; Fernandez, N.; Fumeron, F.; Marques-Vidal, P.; Ktorza, A.; Kramer, W.; Schulte, A.; et al. Plasma Dihydroceramides Are Diabetes Susceptibility Biomarker Candidates in Mice and Humans. Cell Rep. 2017, 18, 2269-2279. [CrossRef]

147. Szpigel, A.; Hainault, I.; Carlier, A.; Venteclef, N.; Batto, A.F.; Hajduch, E.; Bernard, C.; Ktorza, A.; Gautier, J.F.; Ferre, P.; et al. Lipid environment induces ER stress, TXNIP expression and inflammation in immune cells of individuals with type 2 diabetes. Diabetologia 2018, 61, 399-412. [CrossRef]

148. Summers, S.A. Could Ceramides Become the New Cholesterol? Cell Metab. 2018, 27, 276-280. [CrossRef] 